\title{
Groundwater Flow and Contaminant Migration in the Cohoes Mélange Lithotectonic Unit: Influence of a Thrust Fault
}

Robert O'Neill, CPG, PG, Brown and Caldwell James Marolda, CPG, PG, Brown and Caldwell Steven Stucker, CPG, National Grid
2016 GSA Northeastern Section Annual Meeting

March 21-23, 2016

Albany, New York

Technical Session:

Integrating Structural Geology and Hydrogeology 


\section{Regional Setting Former MGP Site, Cohoes, New York}

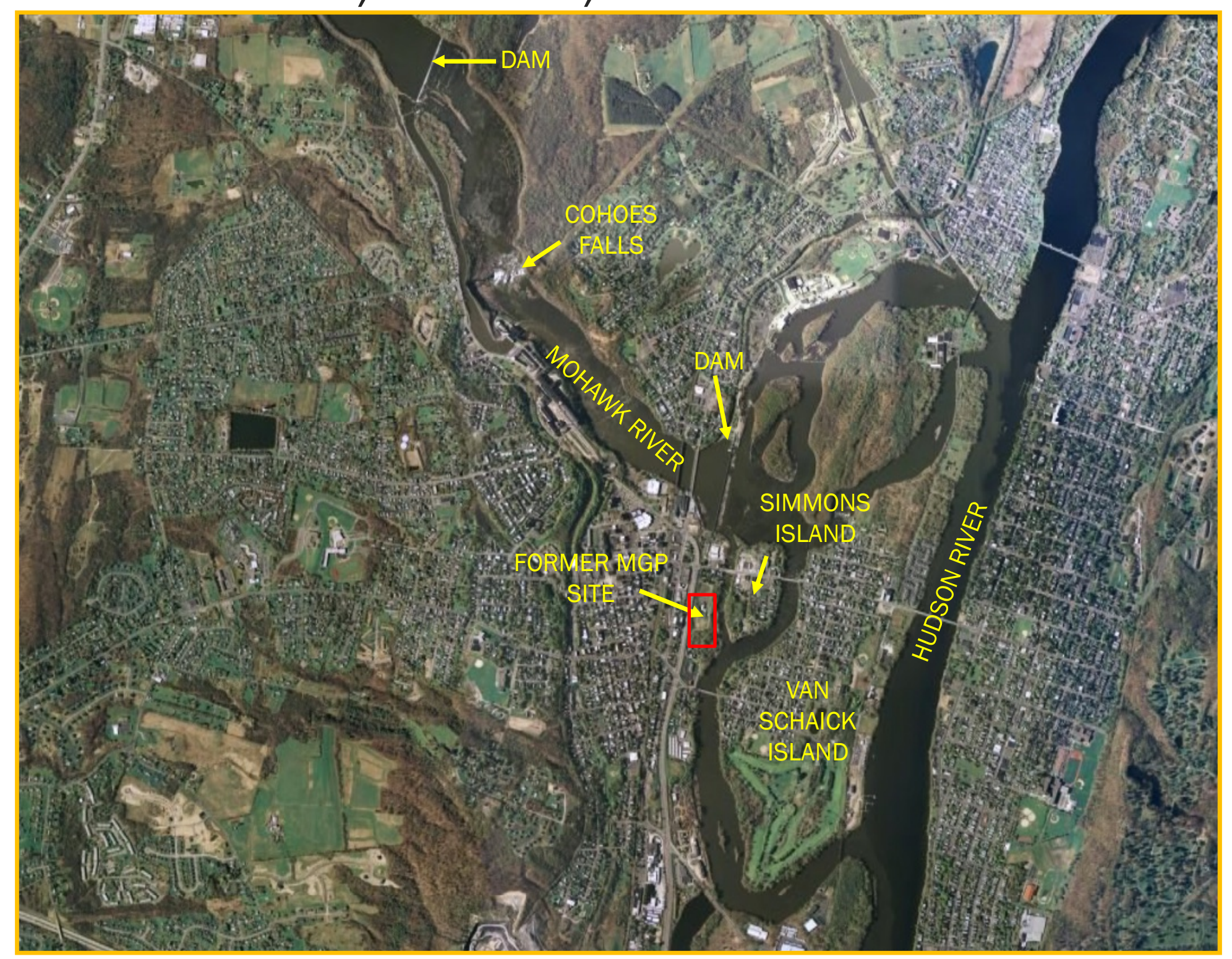




\section{Former MGP Site, Cohoes, New York}

- Primary impact associated with Manufactured Gas Plant (MGP) operations was the release of tar, which typically behaves as a DNAPL.

- Tar is source of dissolvedphase constituents to groundwater such as benzene, toluene, ethylbenzene, xylenes, and naphthalene.

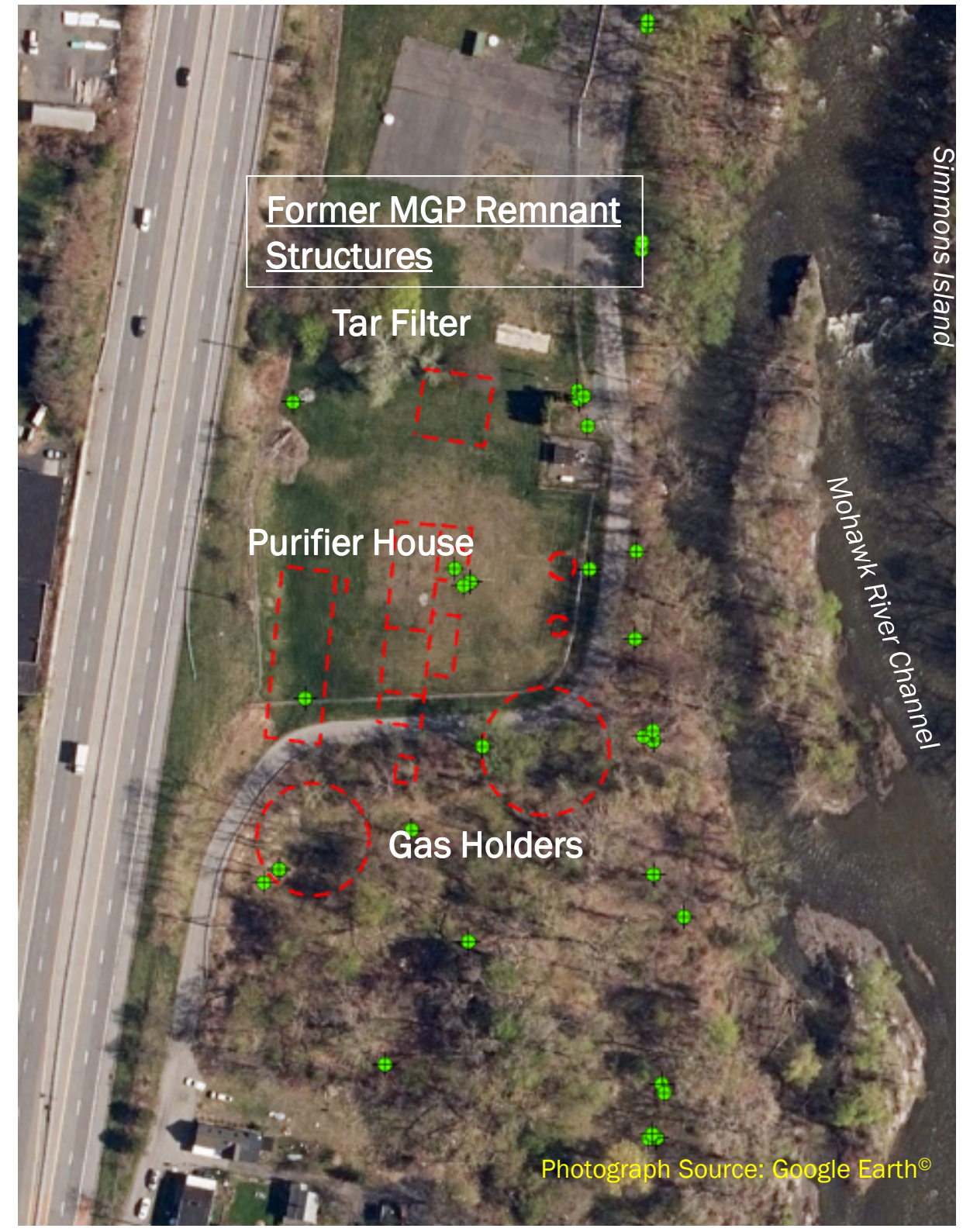




\section{Purpose of Presentation}

- To describe development of a conceptual model of groundwater flow, DNAPL (tar) migration and dissolvedphase constituent migration in highly-deformed sedimentary rock sequence at a former Manufactured Gas Plant (MGP), including discussion of:

- Investigation approach;

- How understanding the regional structural characteristics of the rock facilitated development of the conceptual model and guided the investigation; and

- $\quad$ The influence of a thrust fault on groundwater flow and contaminant migration. 


\section{Bedrock-New York}

From: Rogers, Isachsen, Mock, \& Nyahay, 1990

PLATE 2 GEOLOGIC MAP AND CROSS SECTIONS

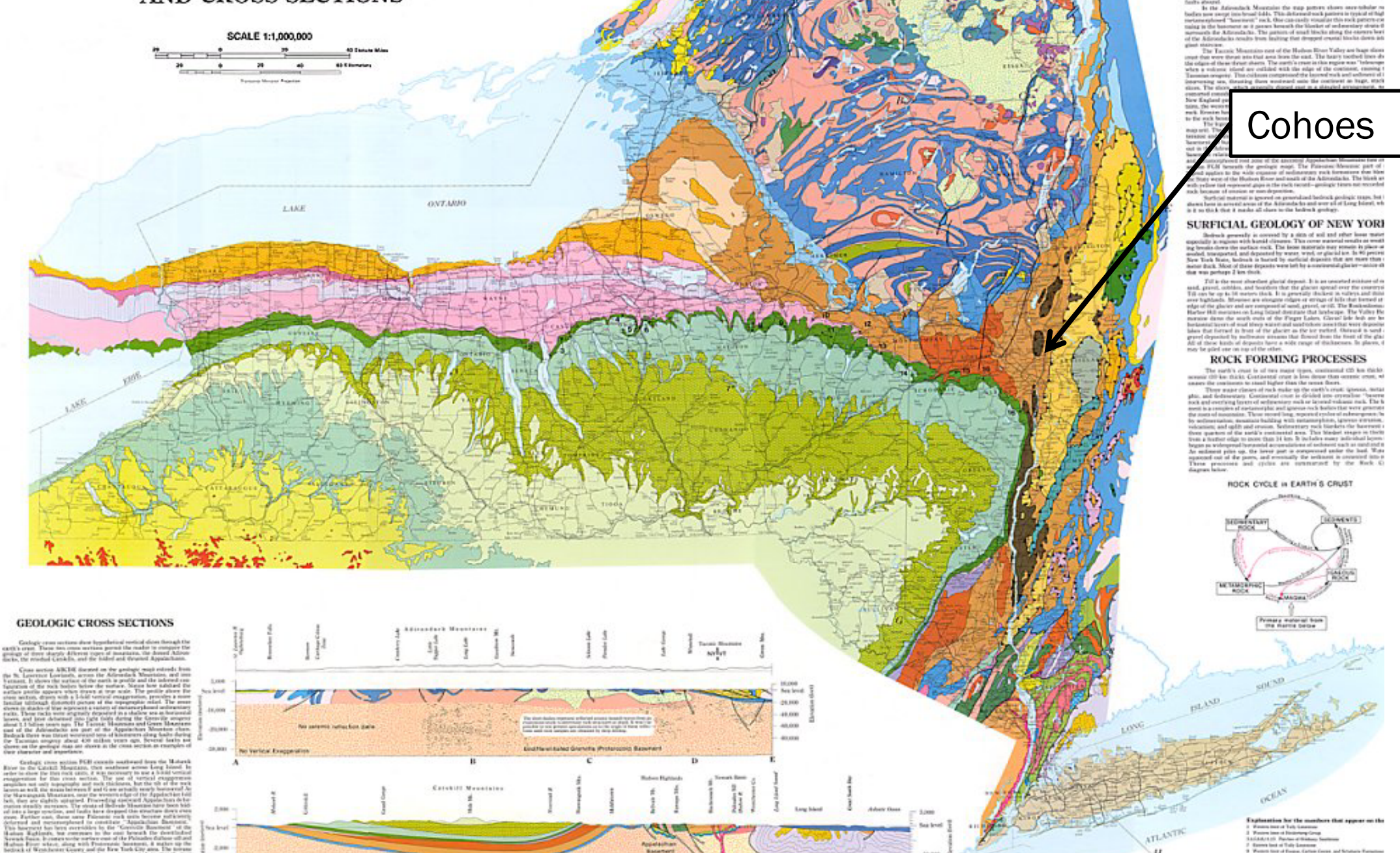




\section{Lithotectonic Map}

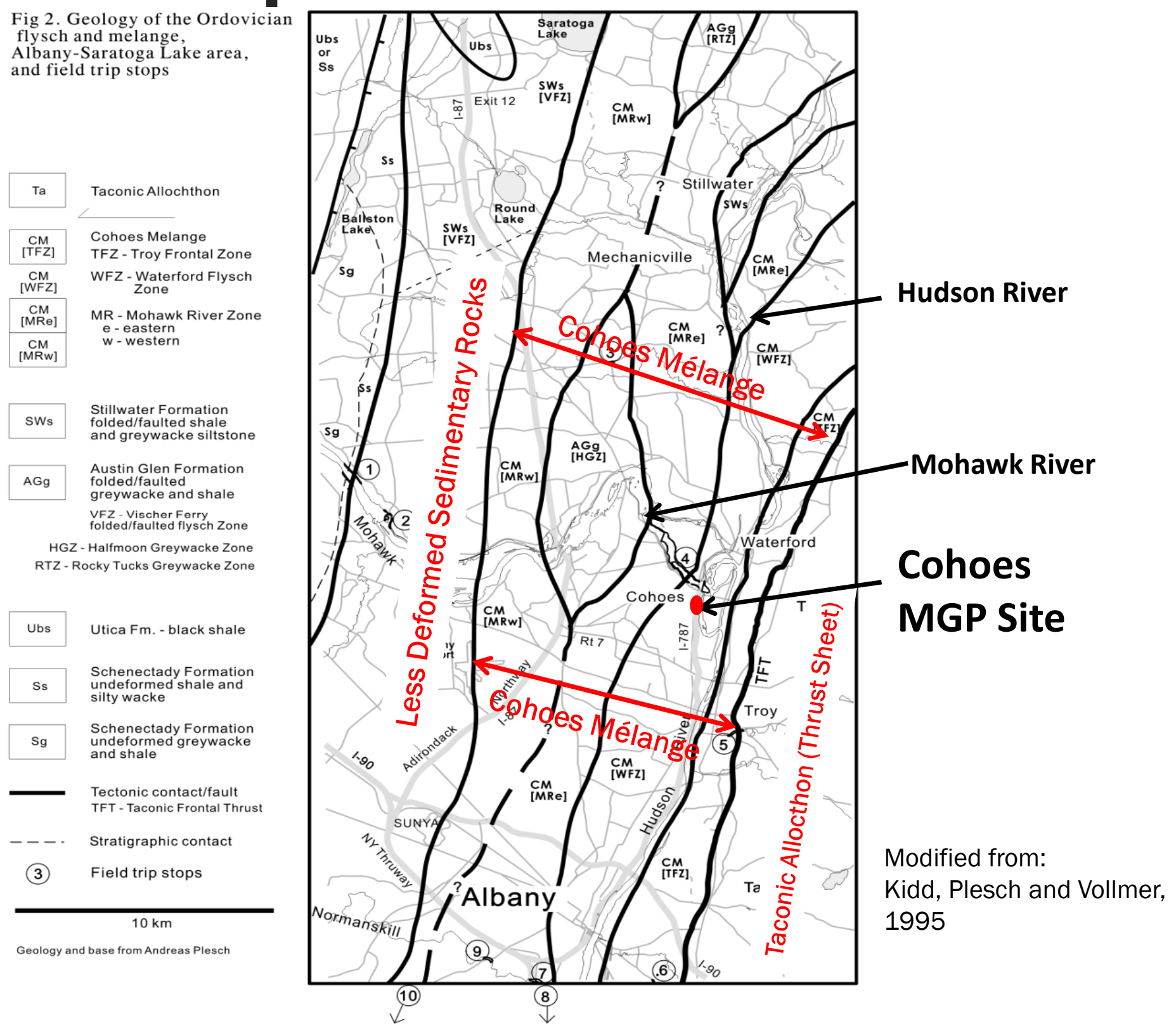




\section{Bedrock Conditions at Cohoes MGP Site: Deformed Sedimentary Rock}

- “Cohoes Mélange" Lithotectonic Unit.

- Originally bedded shale and mudstone unit with some sandstone and siltstone beds.

- Deformed in shear zone during Taconic mountain building event (Ordovician Period).

- Ductile and brittle deformation: Faults, folds, disrupted bedding, closely-spaced cleavage

- No continuous marker beds remain for stratigraphic correlation. Nearly uniform lithology.

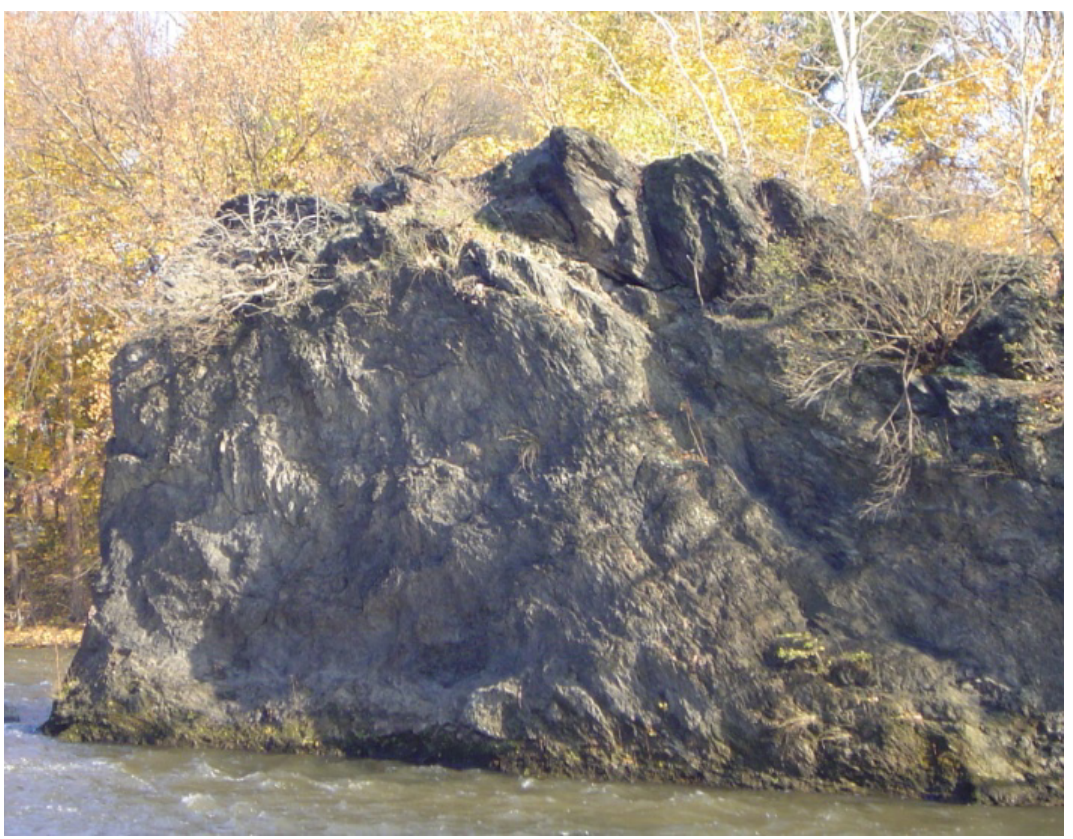

Outcrop of Cohoes Mélange in river channel adjacent to site

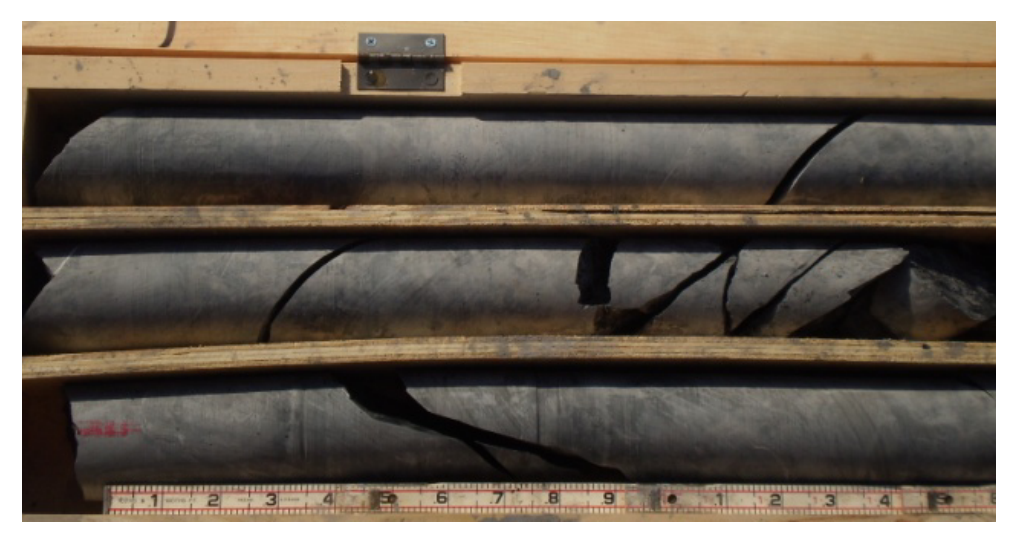

Rock core from Cohoes Mélange: shale w/no visible beds. Breaks are along cleavage. 


\section{Taconic Mountain Building Event Schematic Cross-Section}

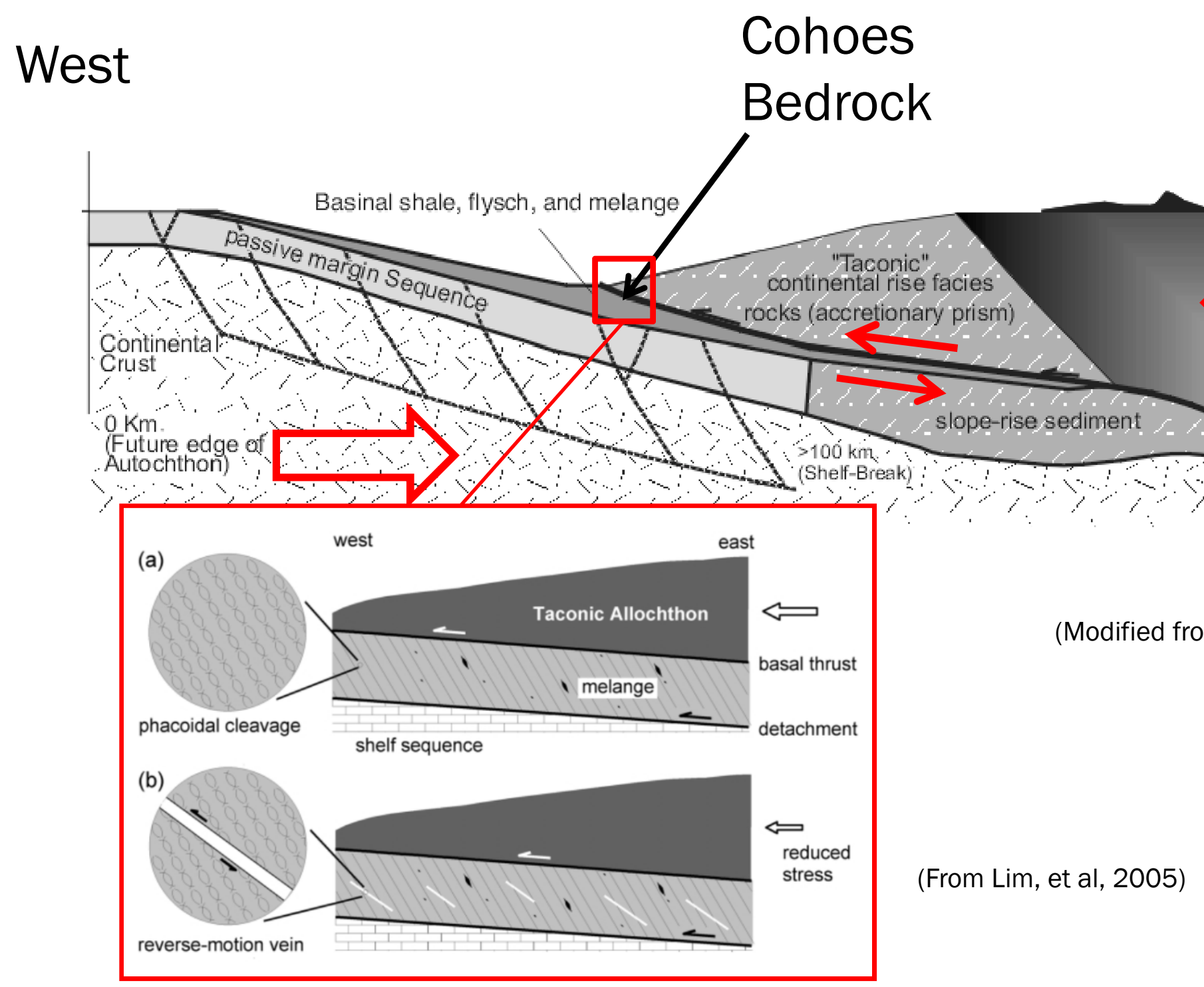

East

olcanic

center

center

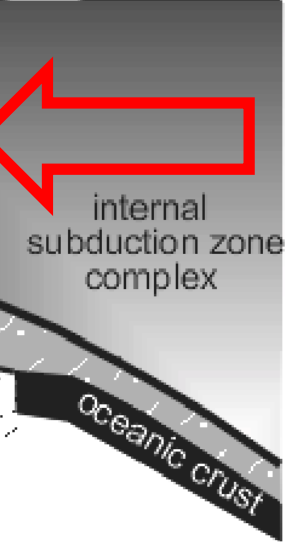

(Modified from Hayman and Kidd, 2002) 


\section{Deformation of Sedimentary Bedrock at Cohoes MGP Site}

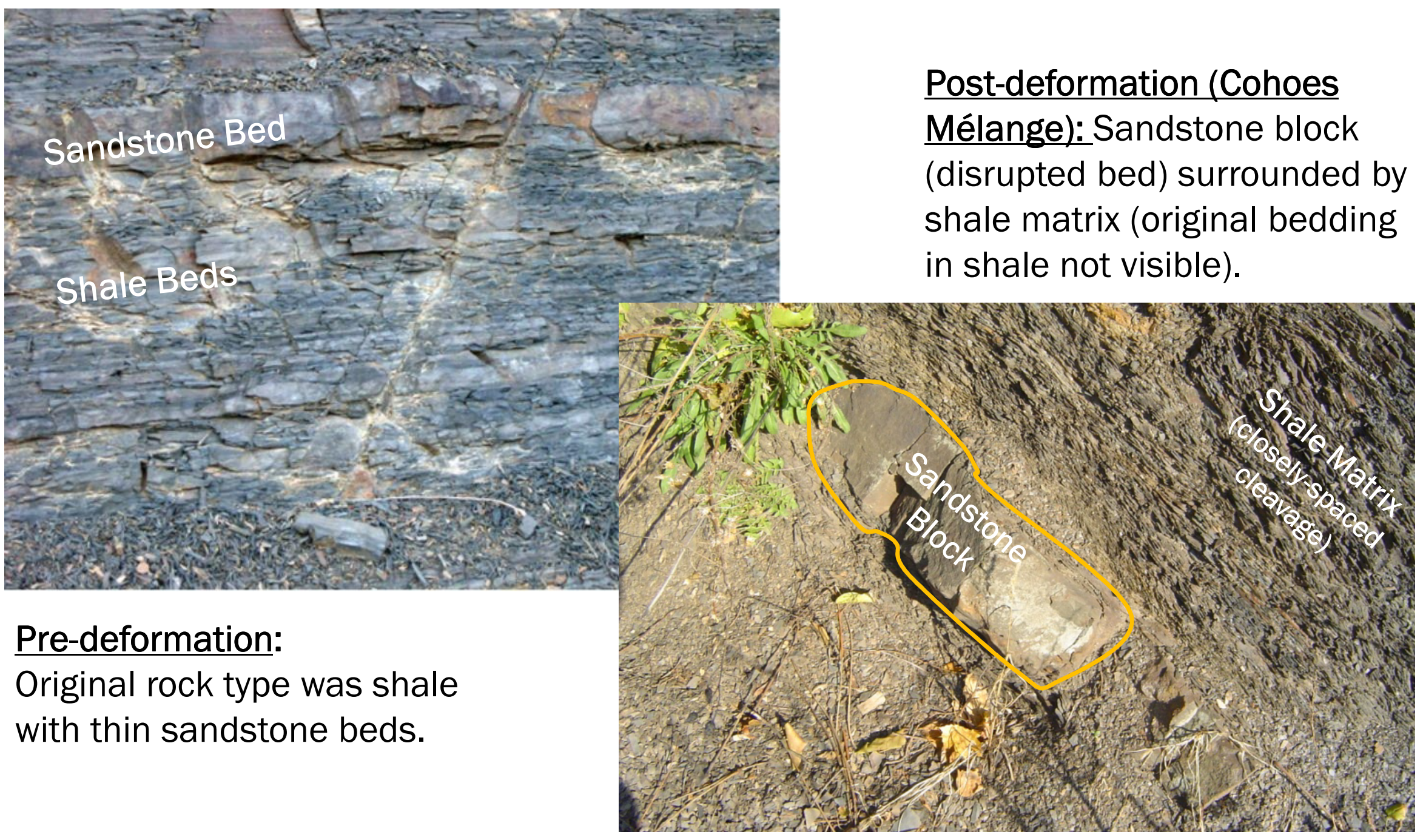




\section{Cohoes Mélange - Outcrop Near Site}

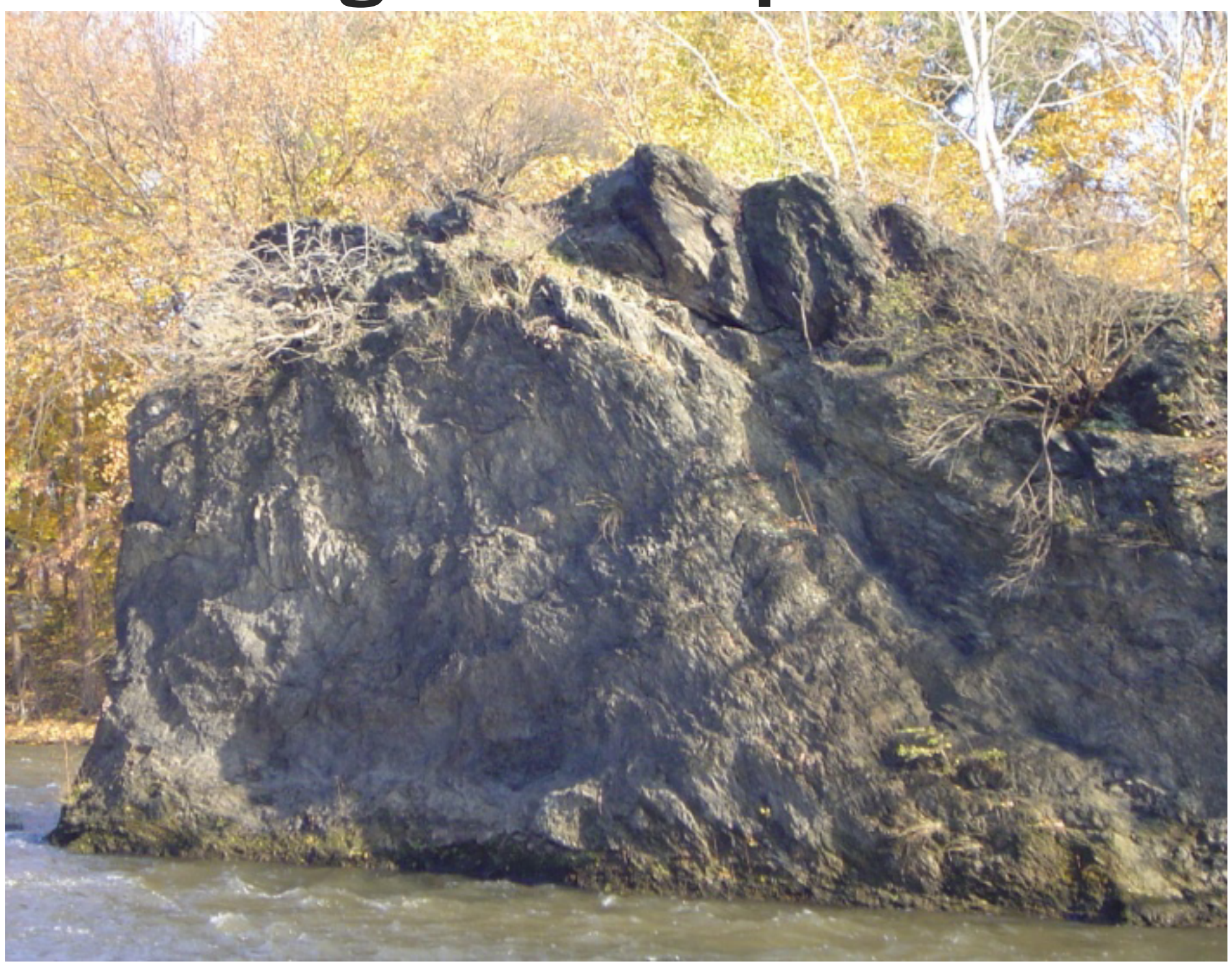




\section{Cohoes Mélange - Outcrops}

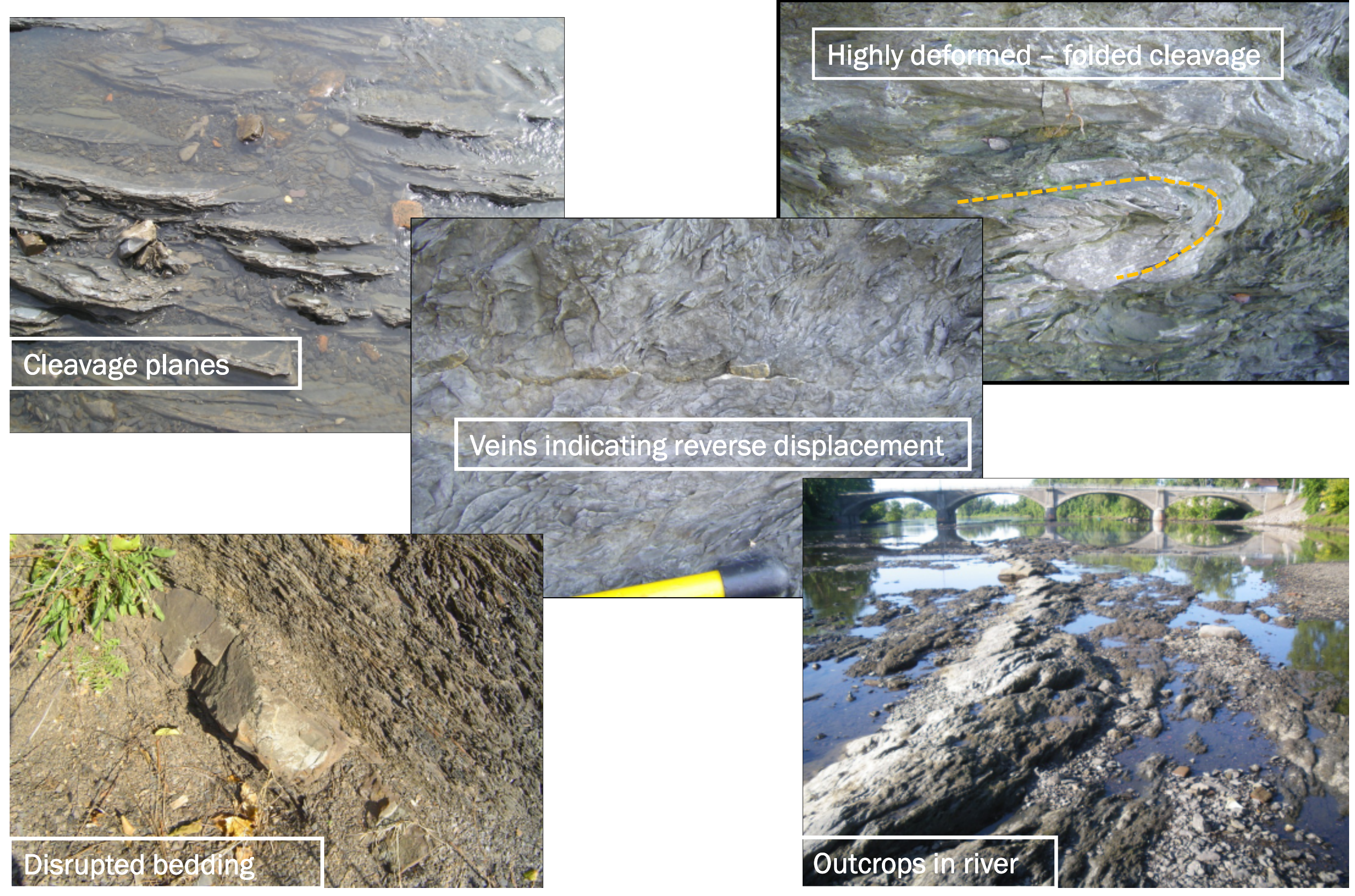




\section{Cohoes Mélange - Core from Site}
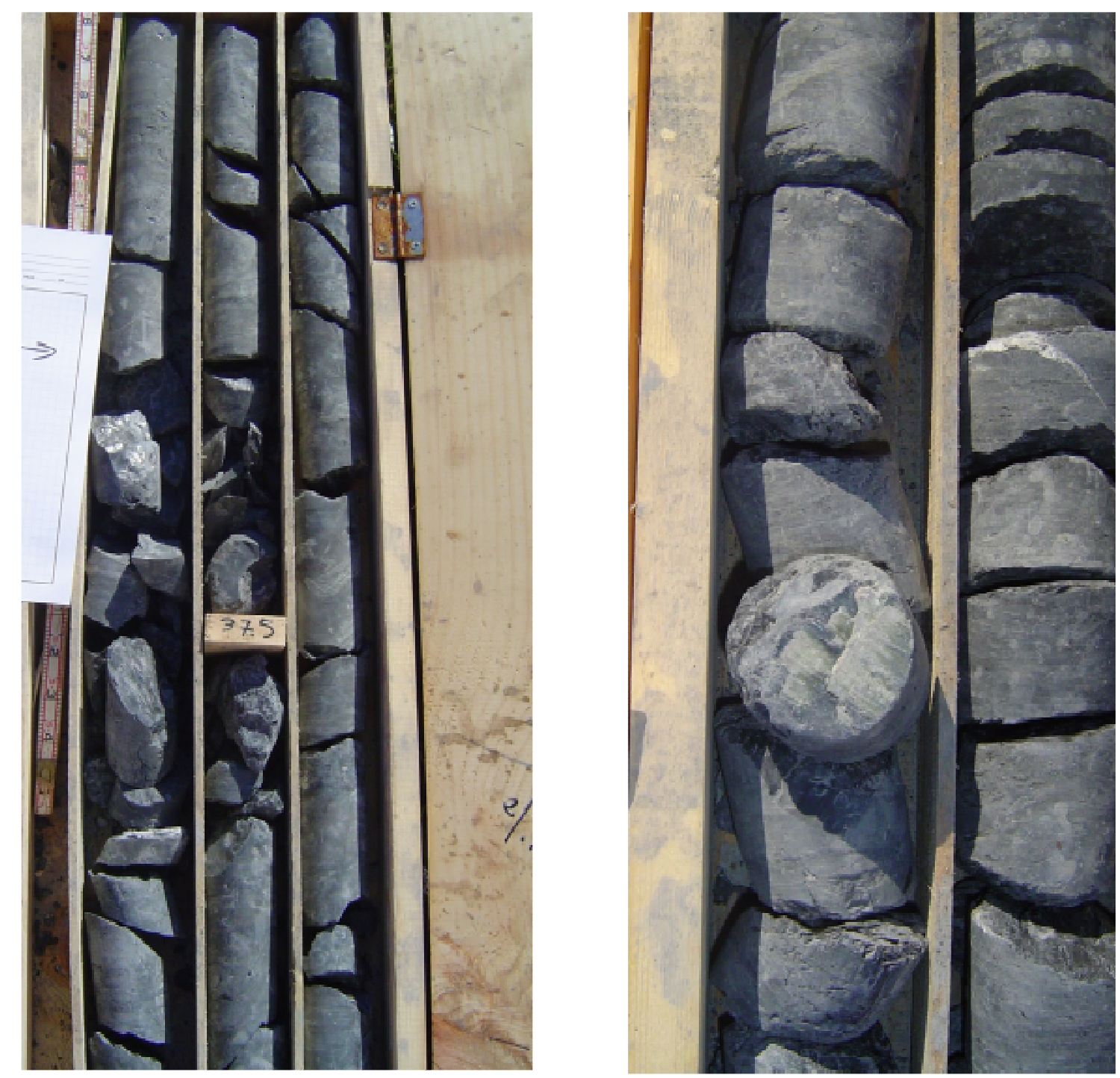

NAPL observations in core

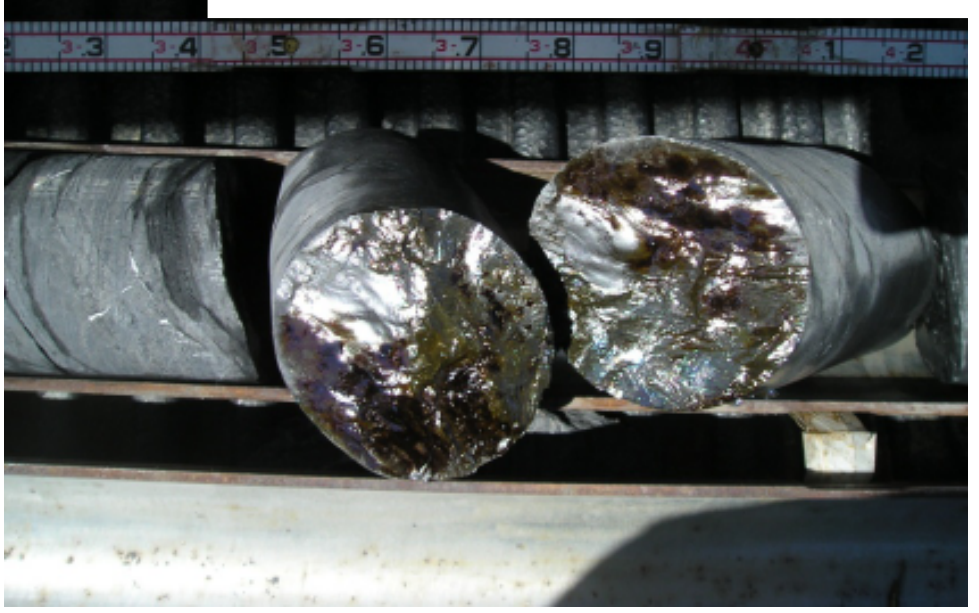




\section{Locations for Bedrock Evaluation/Wells: Initial Phase of Investigation}

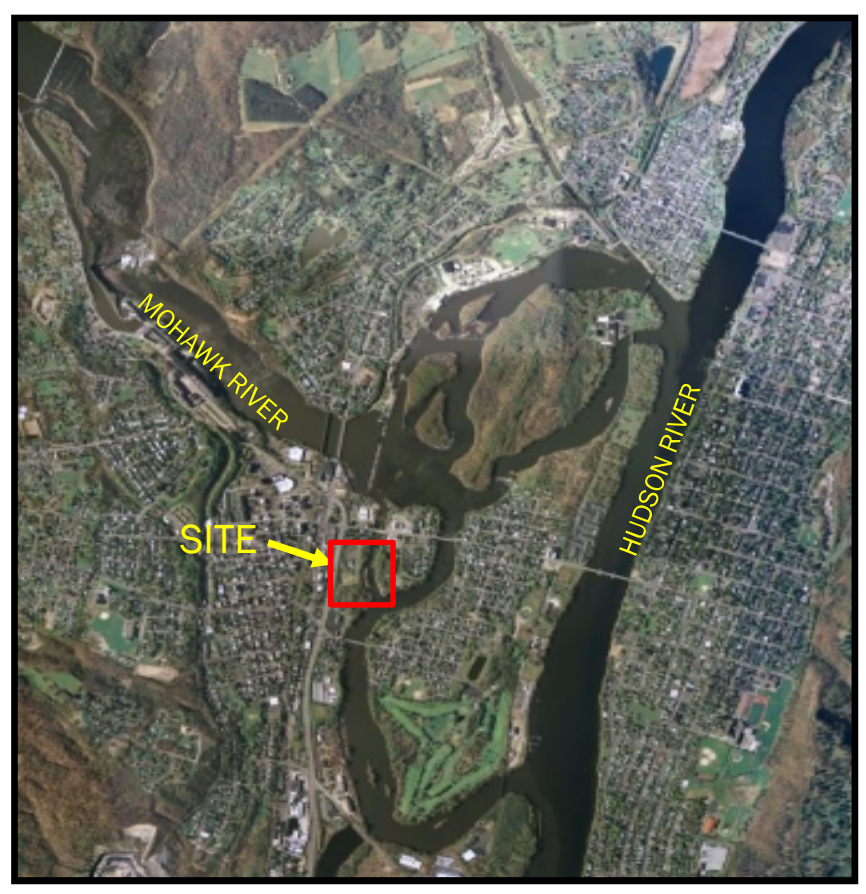

Bedrock evaluation and well location, initial phase

B B' Line of cross-section

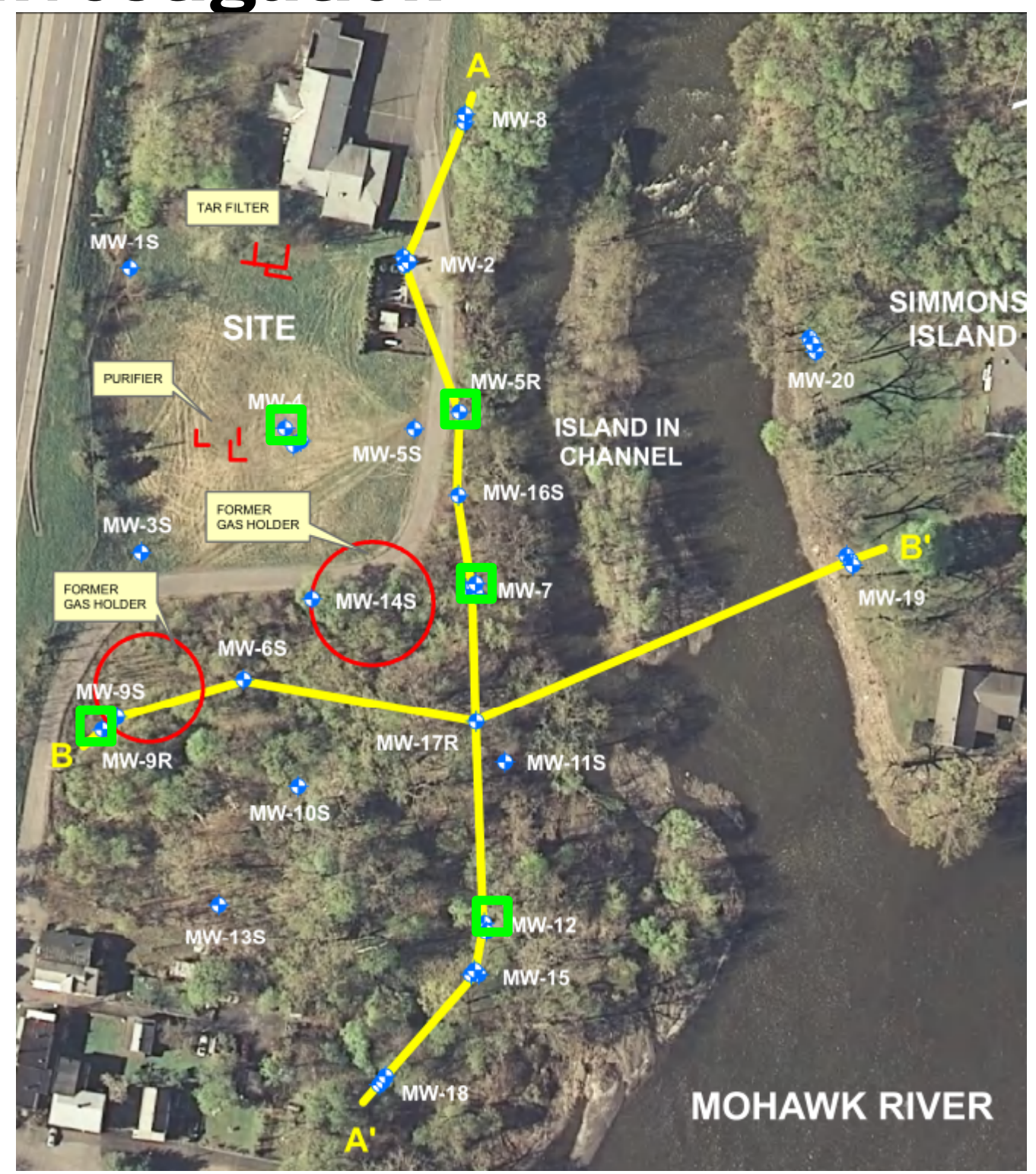




\section{Bedrock Evaluation Approach at Individual Locations: Field Data}

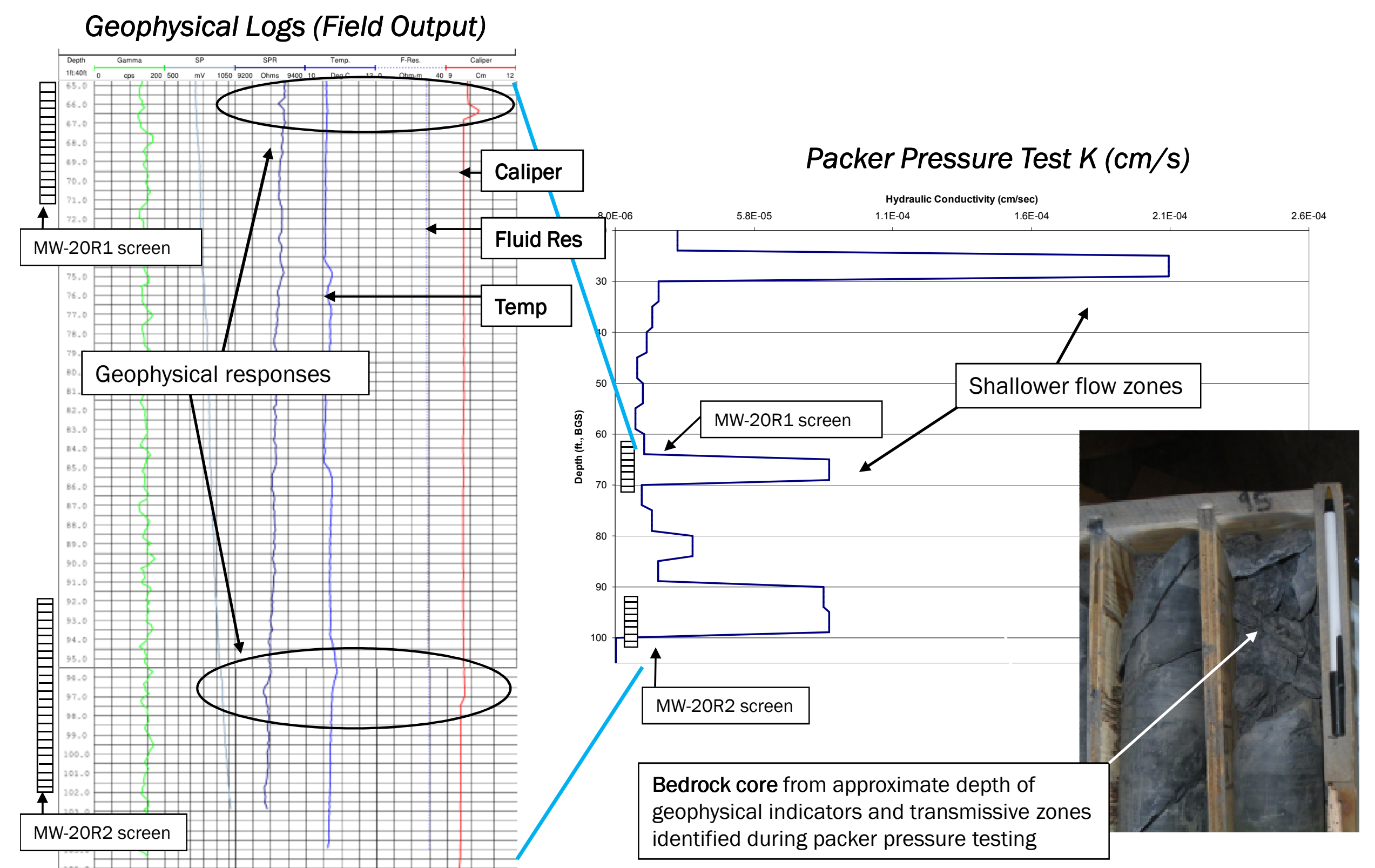




\section{Field/Working Cross-Section: Continuous Fracture Zone}

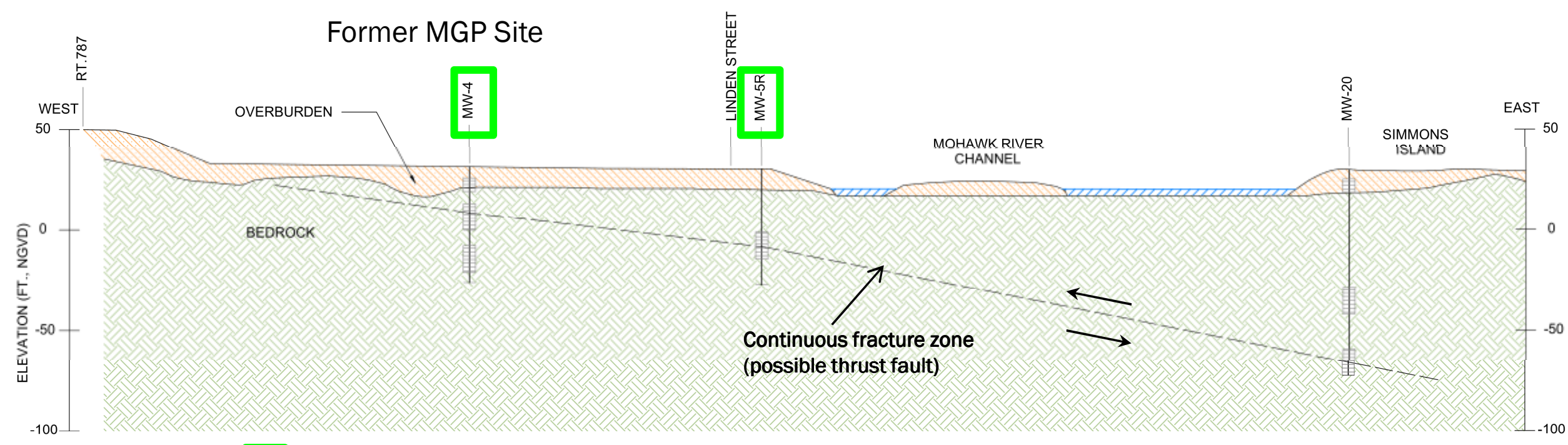

Bedrock evaluation and well location,

initial phase of investigation

- During initial phase: at wells w/ greatest dissolved-phase concentrations, the water-bearing fractures intersecting the screen plotted on an east-dipping plane.

- Geometry of plane is similar to thrust faults in region.

- Projected plane down-dip and along strike to plan subsequent drilling to evaluate this potentially continuous fracture zone.

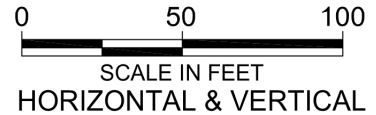

No vertical exaggeration 


\section{Thrust Fault Elevation Contours}

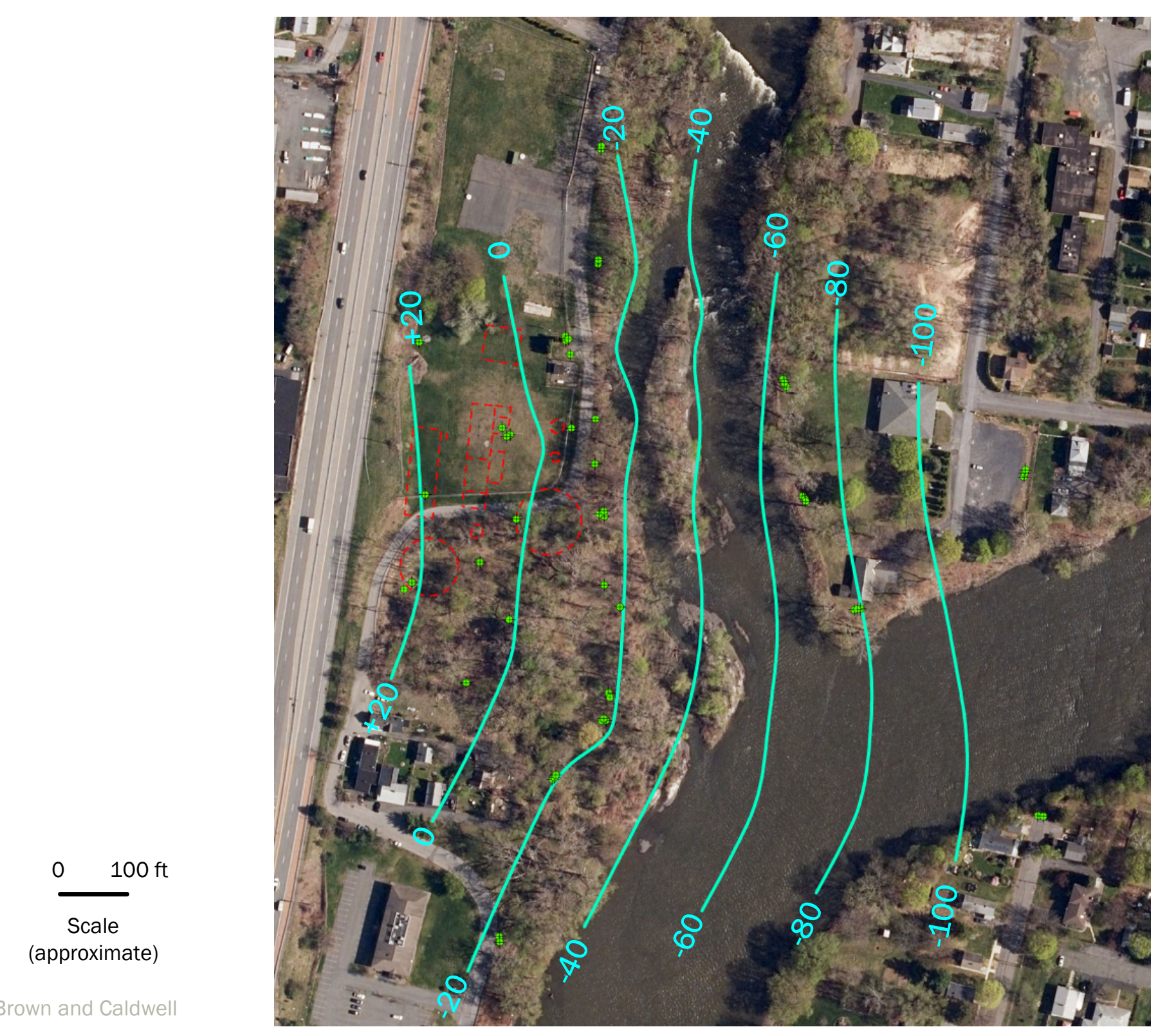

Contour units: feet, NGVD 


\section{Cohoes Mélange Outcrops: Thrust Fault}

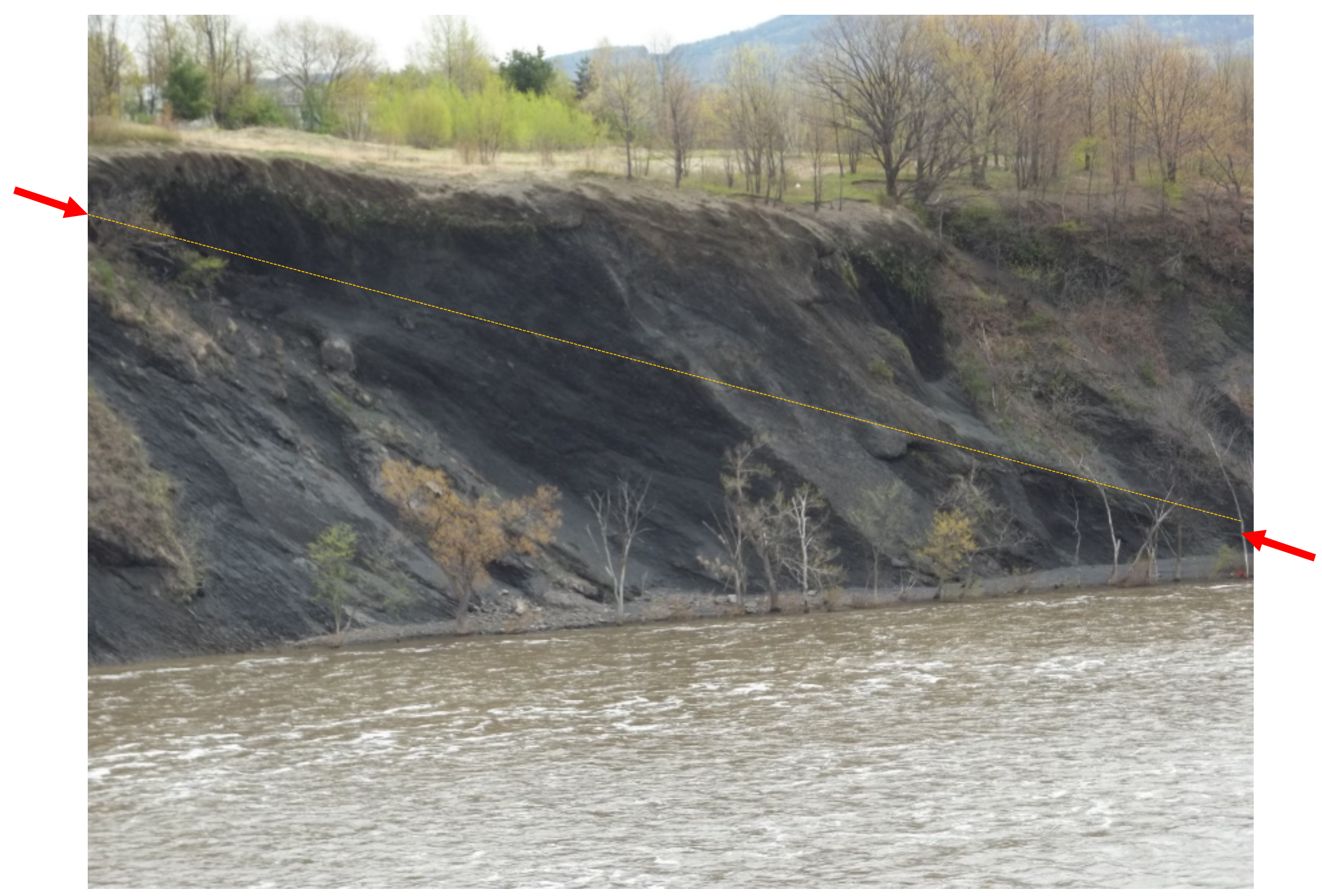




\section{Cohoes Mélange Outcrops: Thrust Fault}

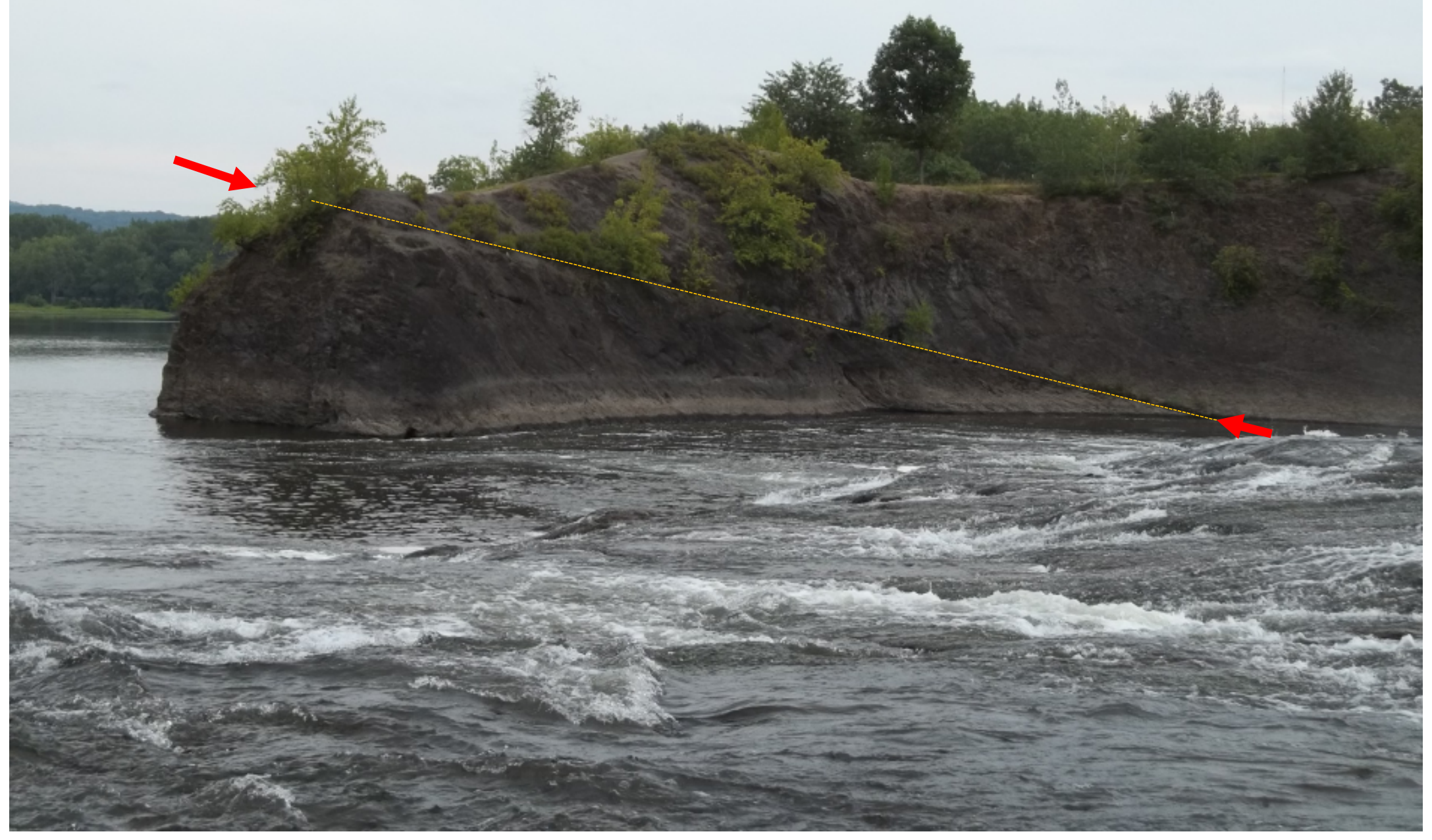




\section{D Model}

Gas Holders (Excavated into bedrock)

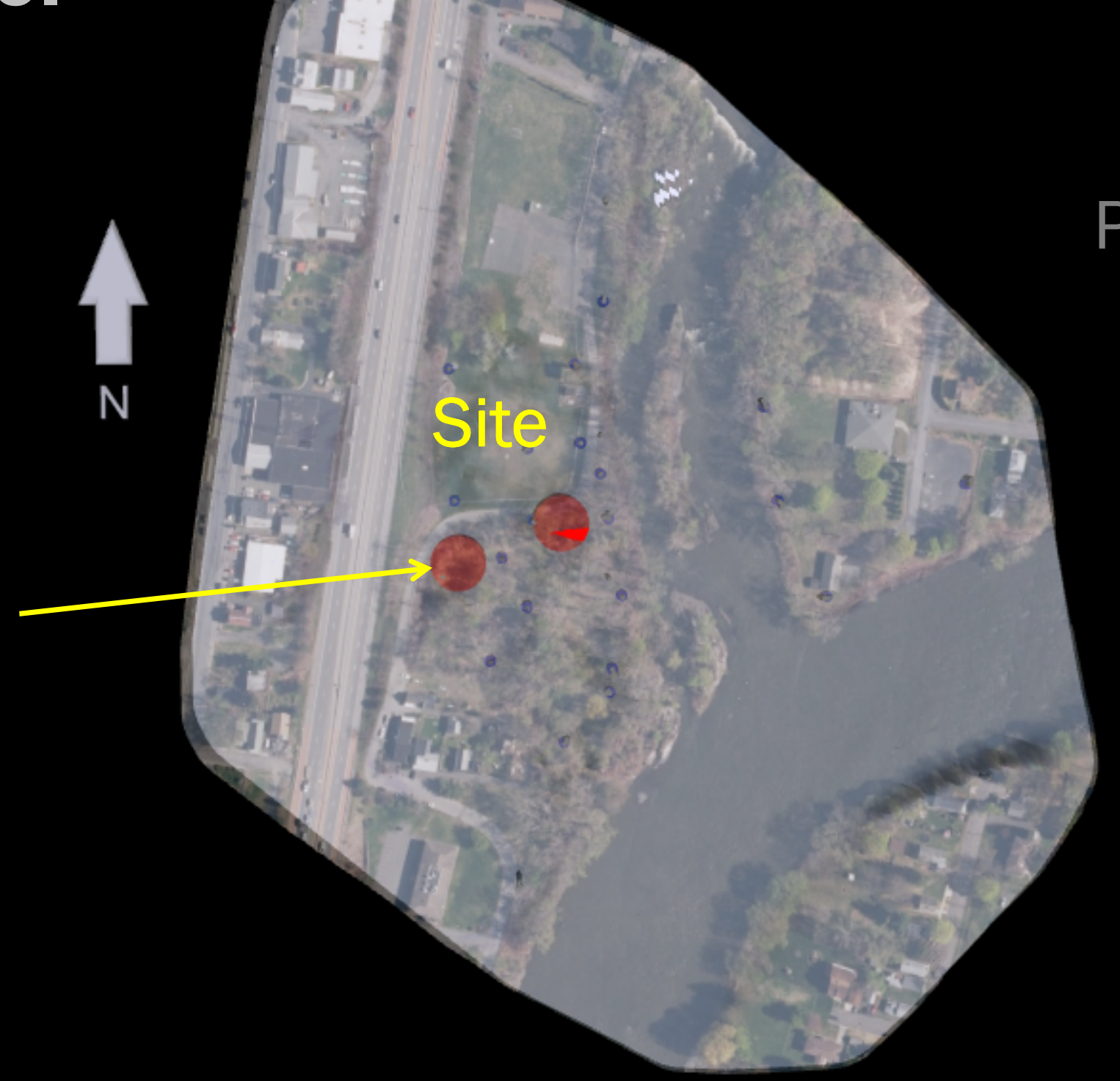

Plan View 


\section{D Model}

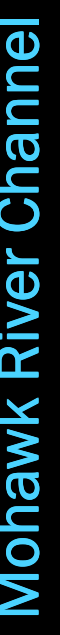

Cross-Section View Toward North

(Vertical Exaggeration 5x)

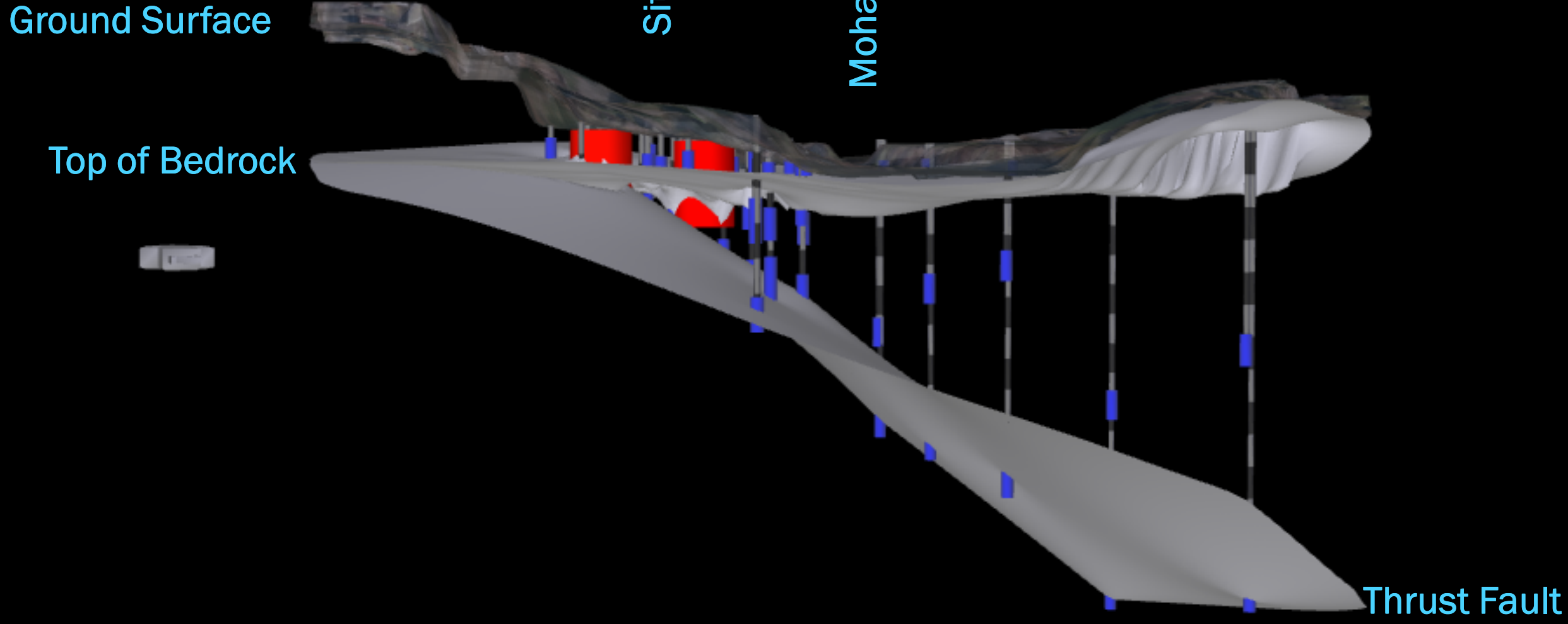




\section{D Model}

\section{Cross-Section View Toward North \\ (No Vertical Exaggeration)}

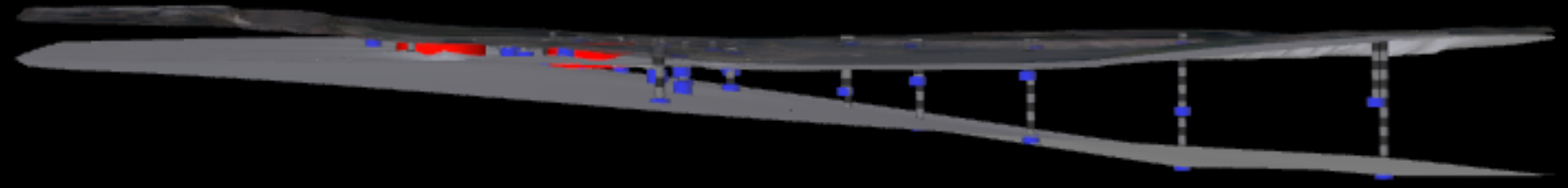

Thrust Fault 


\section{D Model}

\section{Cross-Section View Toward North (Rotated)}

(Vertical Exaggeration 5x)

Shallow position of thrust fault zone beneath western part of site, and its intersection with top of rock surface and gas holder excavation into rock, facilitates entry of impacts into fracture zone

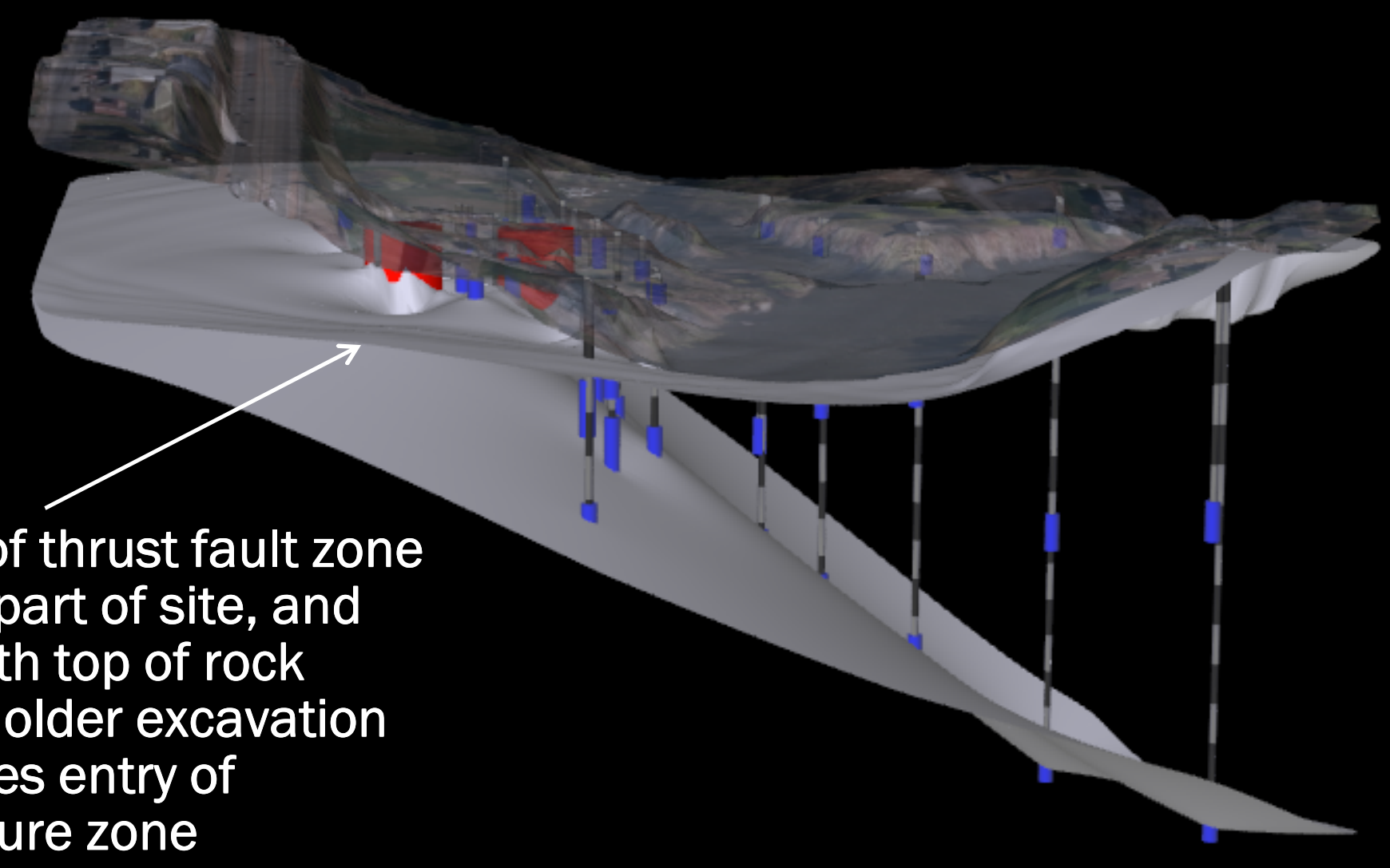

Thrust Fault 


\section{D Model}

Cross-Section View Toward North (Rotated) (Vertical Exaggeration 5x)

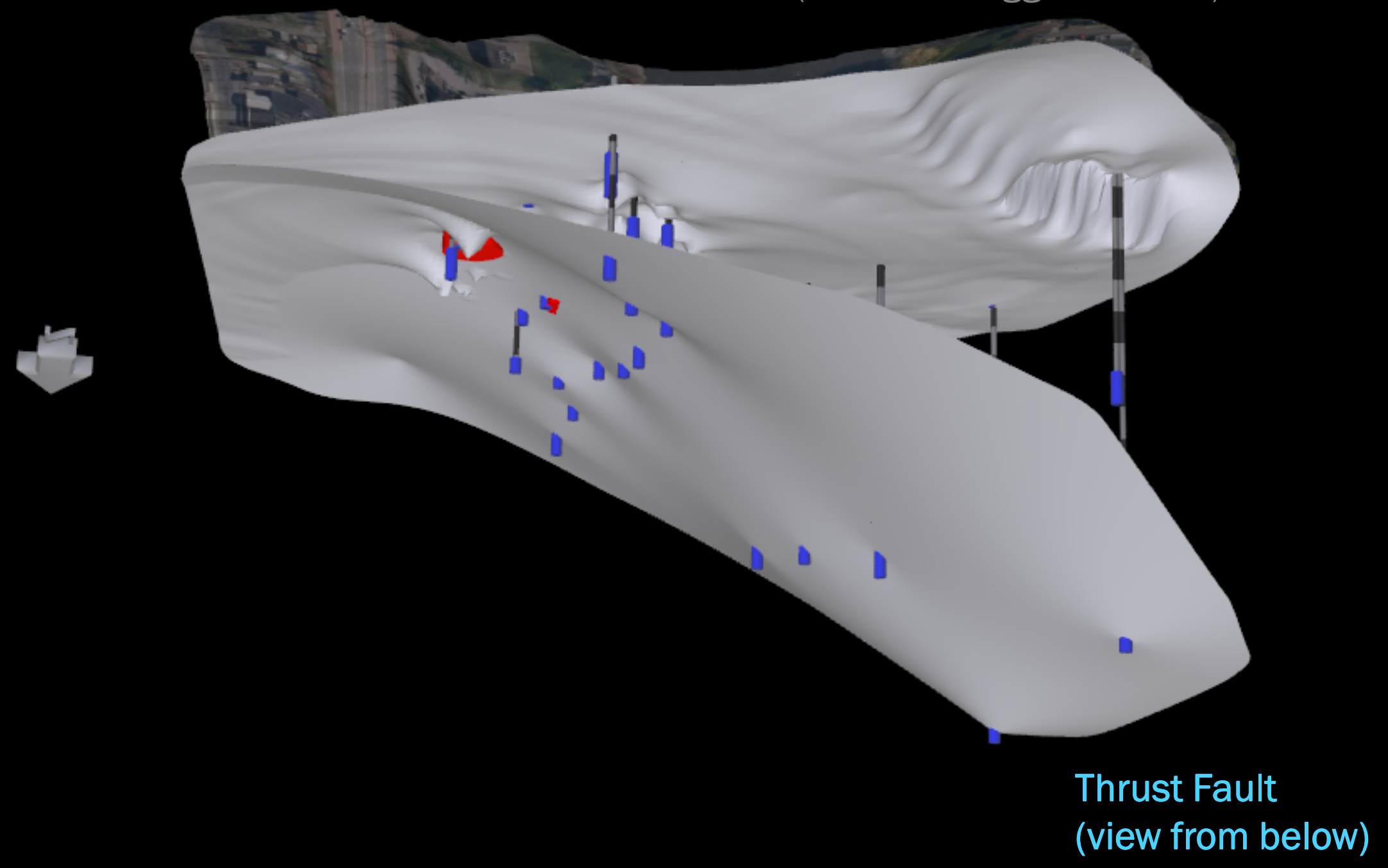




\section{D Model}

Cross-Section View

Toward Southwest

(Vertical Exaggeration 5x)

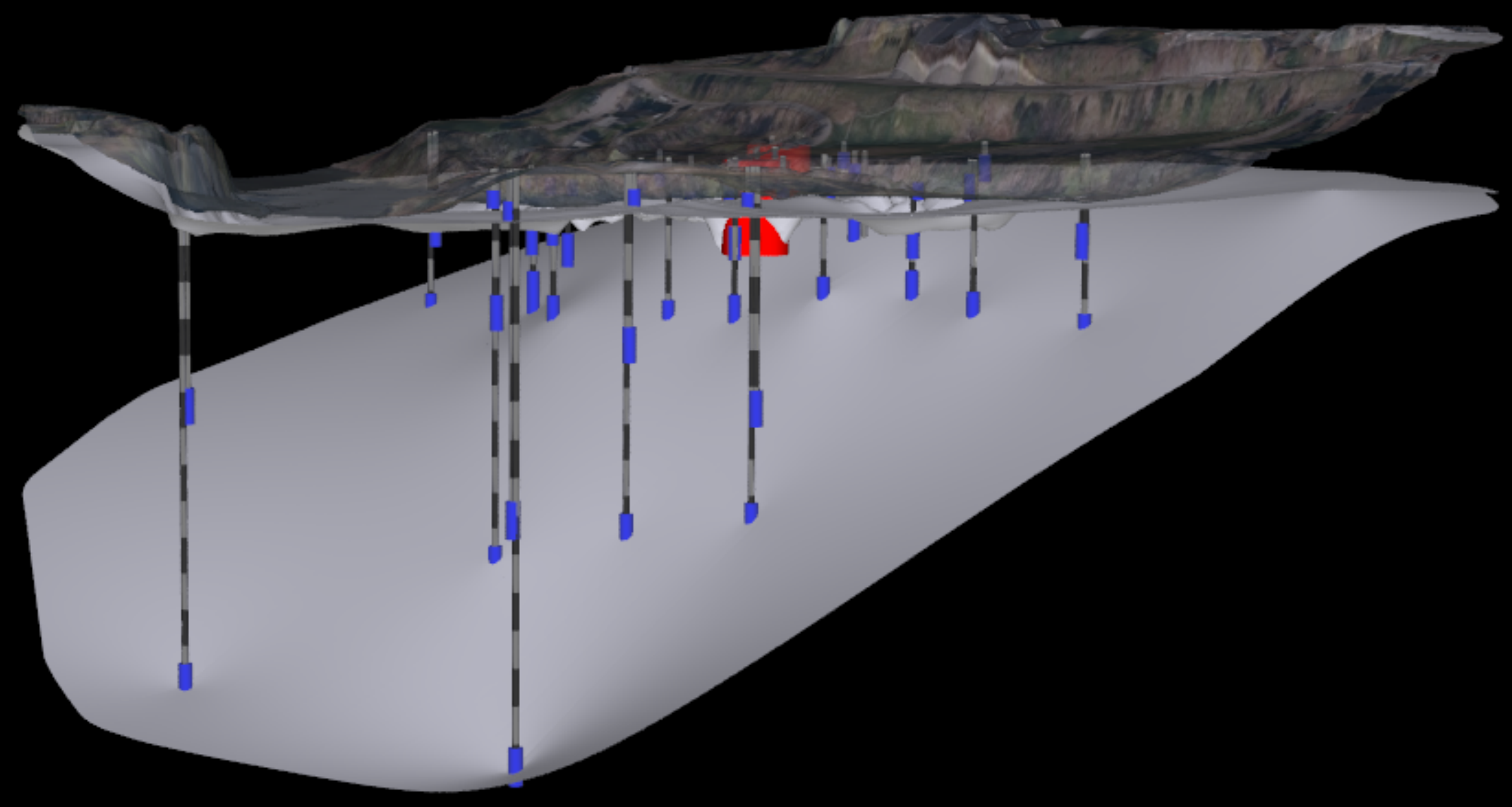

Thrust Fault 


\section{Cross-Section B-B' (West to East)}

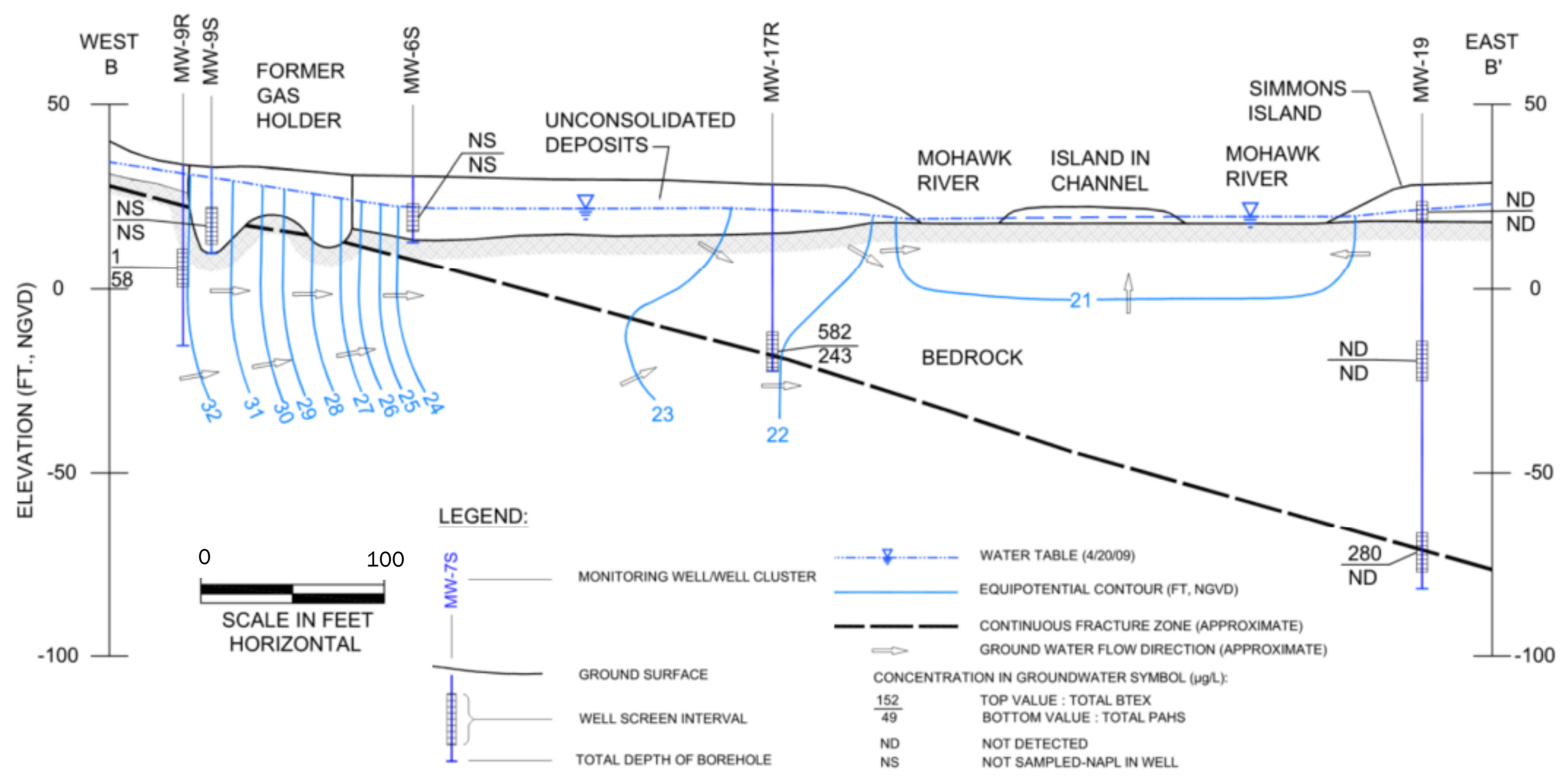

- Beneath Site, hydraulic head is lowest in thrust fault zone

- To east, under river, vertical hydraulic gradient is upward from thrust fault zone toward river 


\section{Pumping Tests-Short Term}

- Four short-term pumping/recovery tests ( $\pm 6-h r$ pumping) were conducted over course of investigation.

- Purpose-Qualitatively assess degree of hydraulic connectivity between:

- $\quad$ Potential bedrock water-bearing zones screened at individual wells at different locations (lateral connectivity)

- $\quad$ Potential water-bearing zones identified at an individual location (vertical connectivity) 


\section{Short-Term Pumping Tests to Evaluate Hydraulic Connectivity}

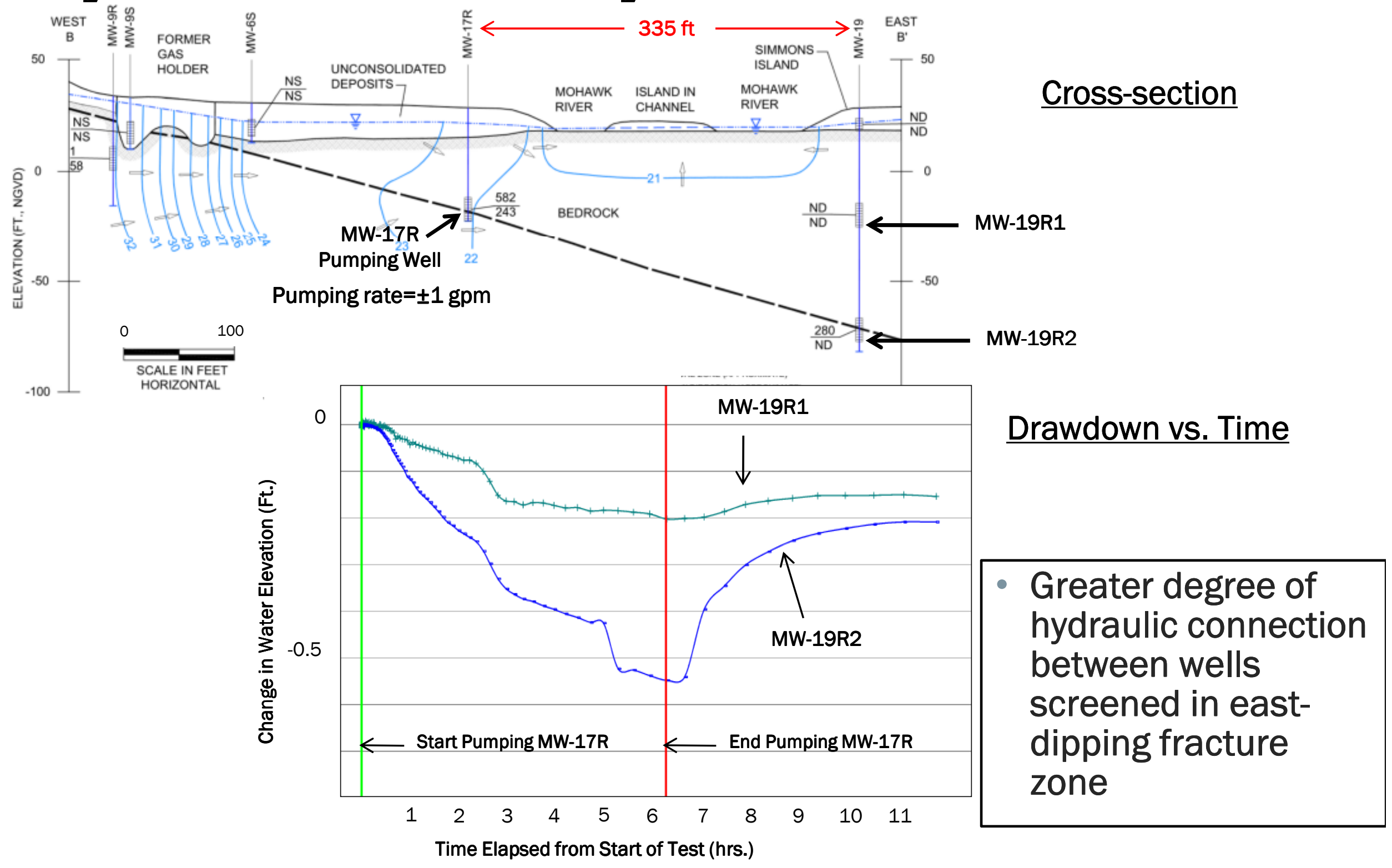




\section{Lateral Groundwater Flow along Fault}

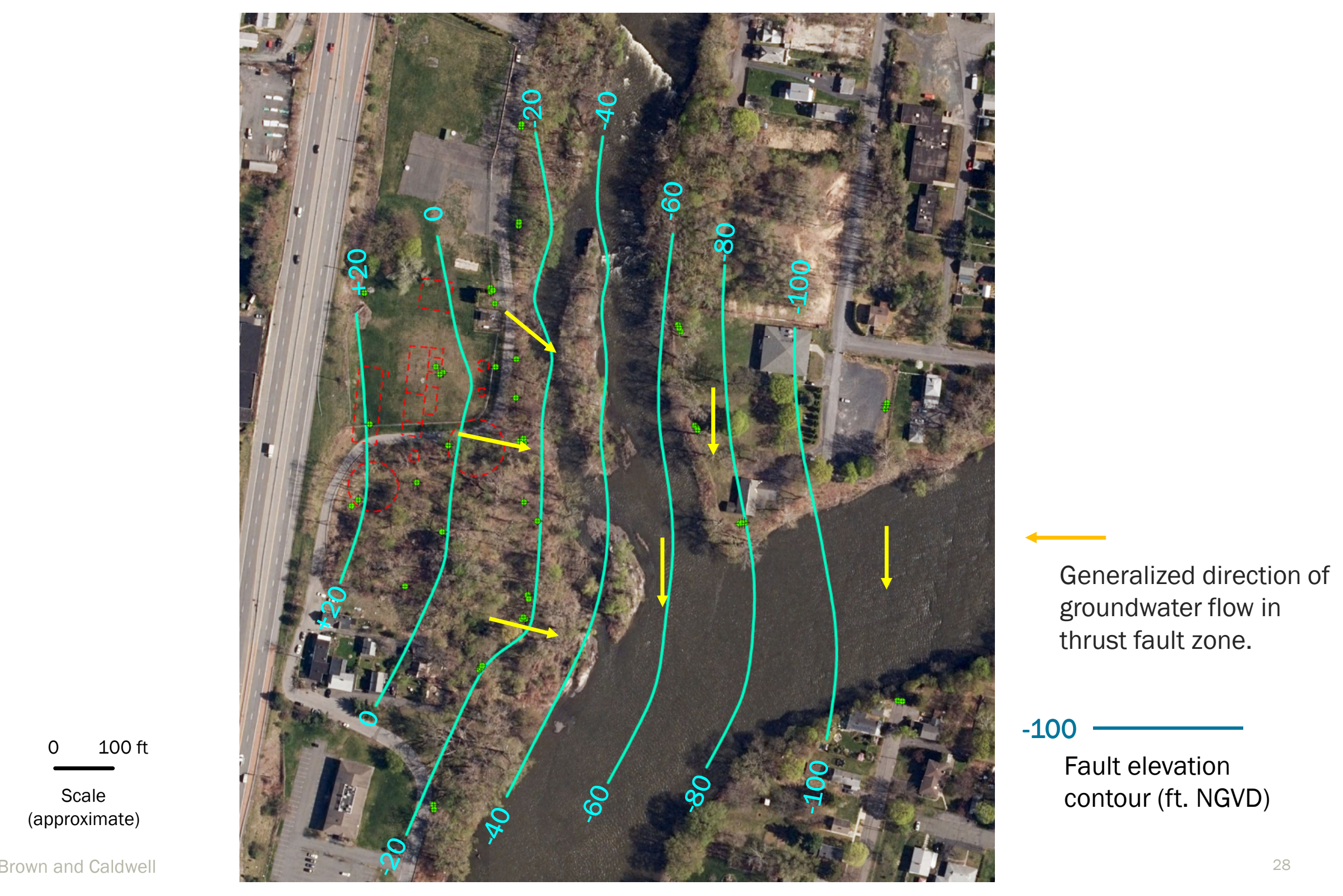




\section{NAPL or Potential NAPL in Bedrock above Fault}

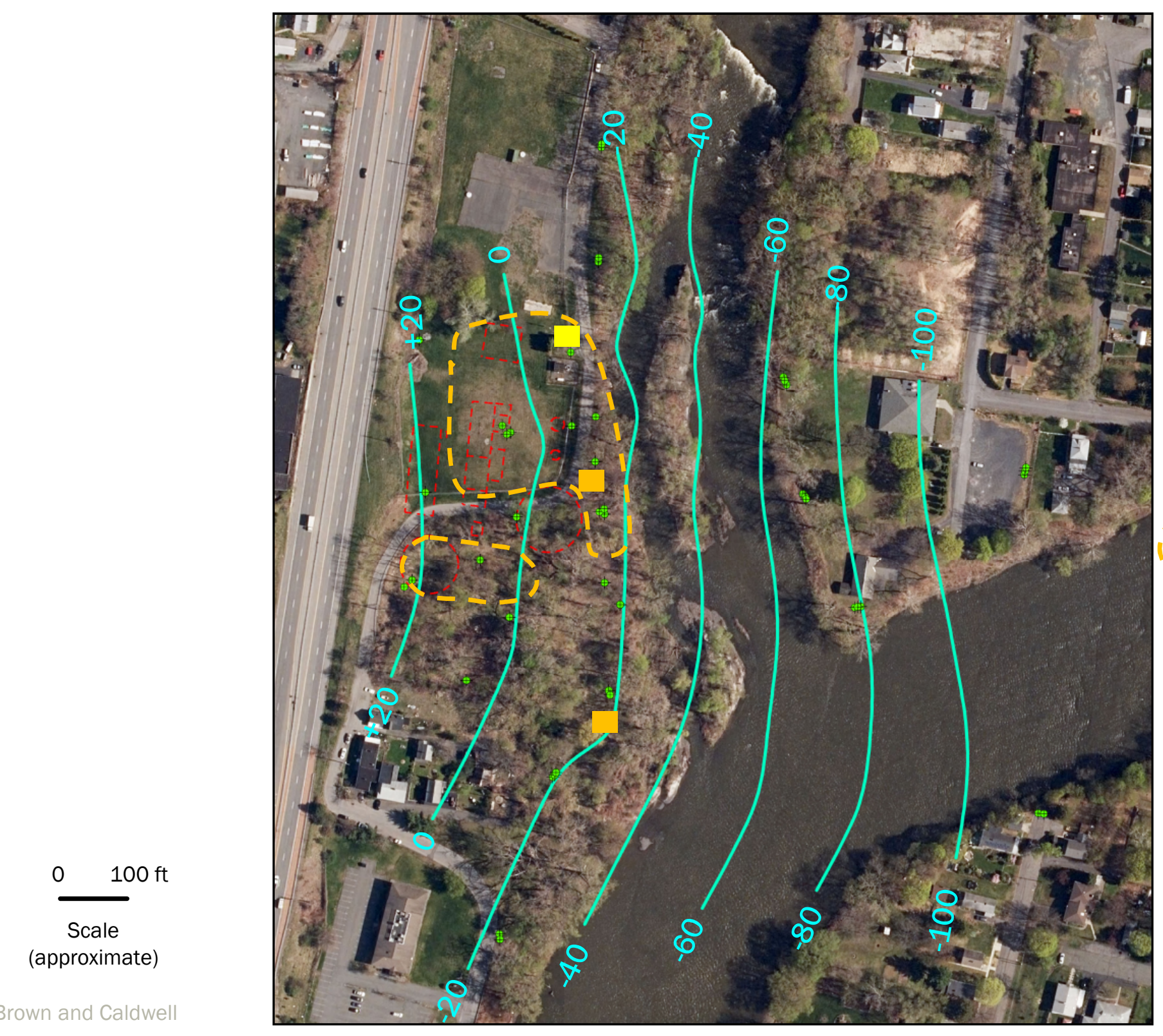

NAPL observed in bedrock well or in rock core

- NAPL potentially in vicinity of bedrock well screen based on dissolved-phase concentrations

- Approximate area of

DNAPL in overburden on top of bedrock (primarily residual, locally saturated)

Fault elevation contour (ft. NGVD) 


\section{NAPL or Potential NAPL in Fault}

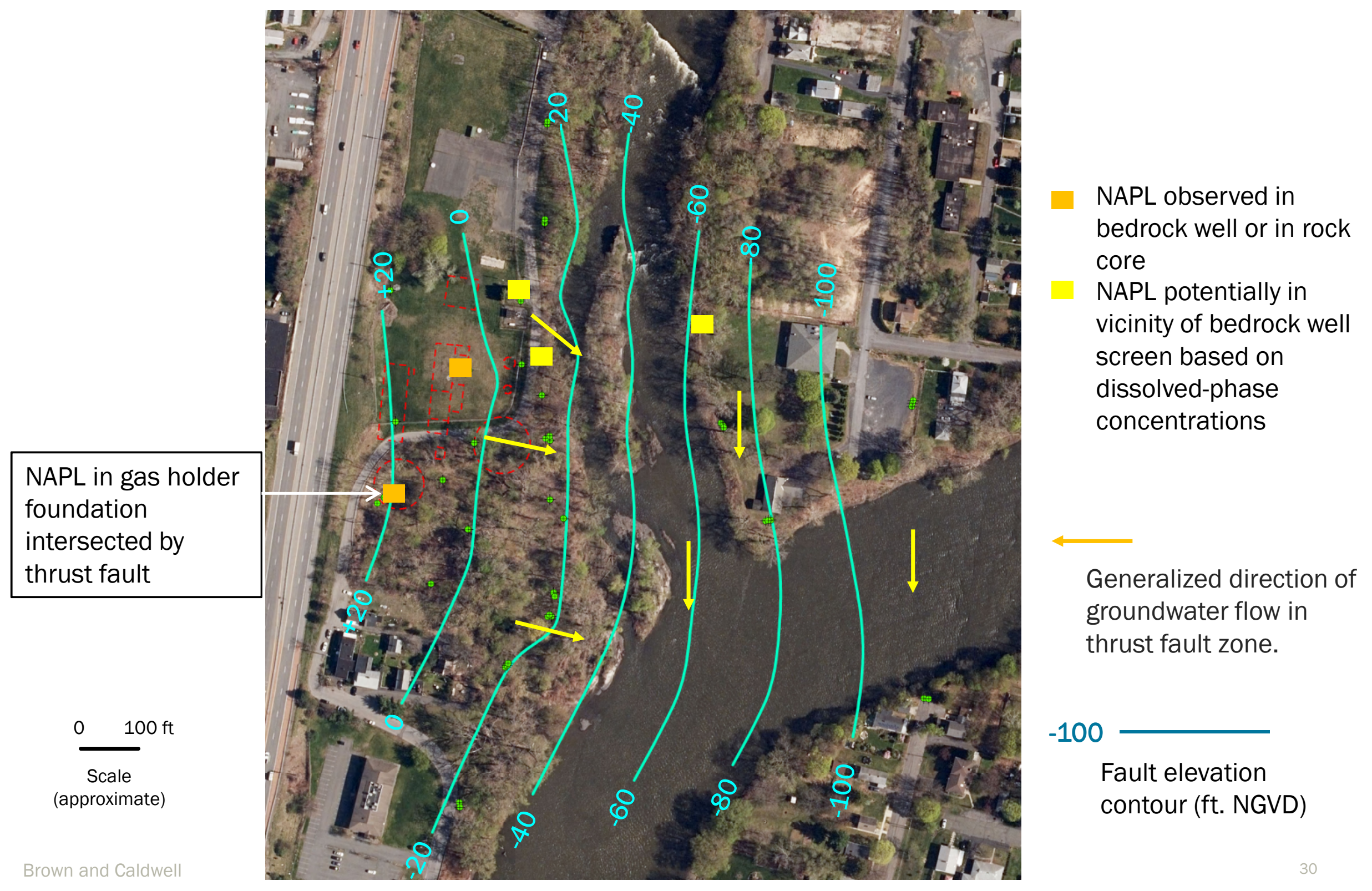




\section{Naphthalene in Bedrock Groundwater above Fault}

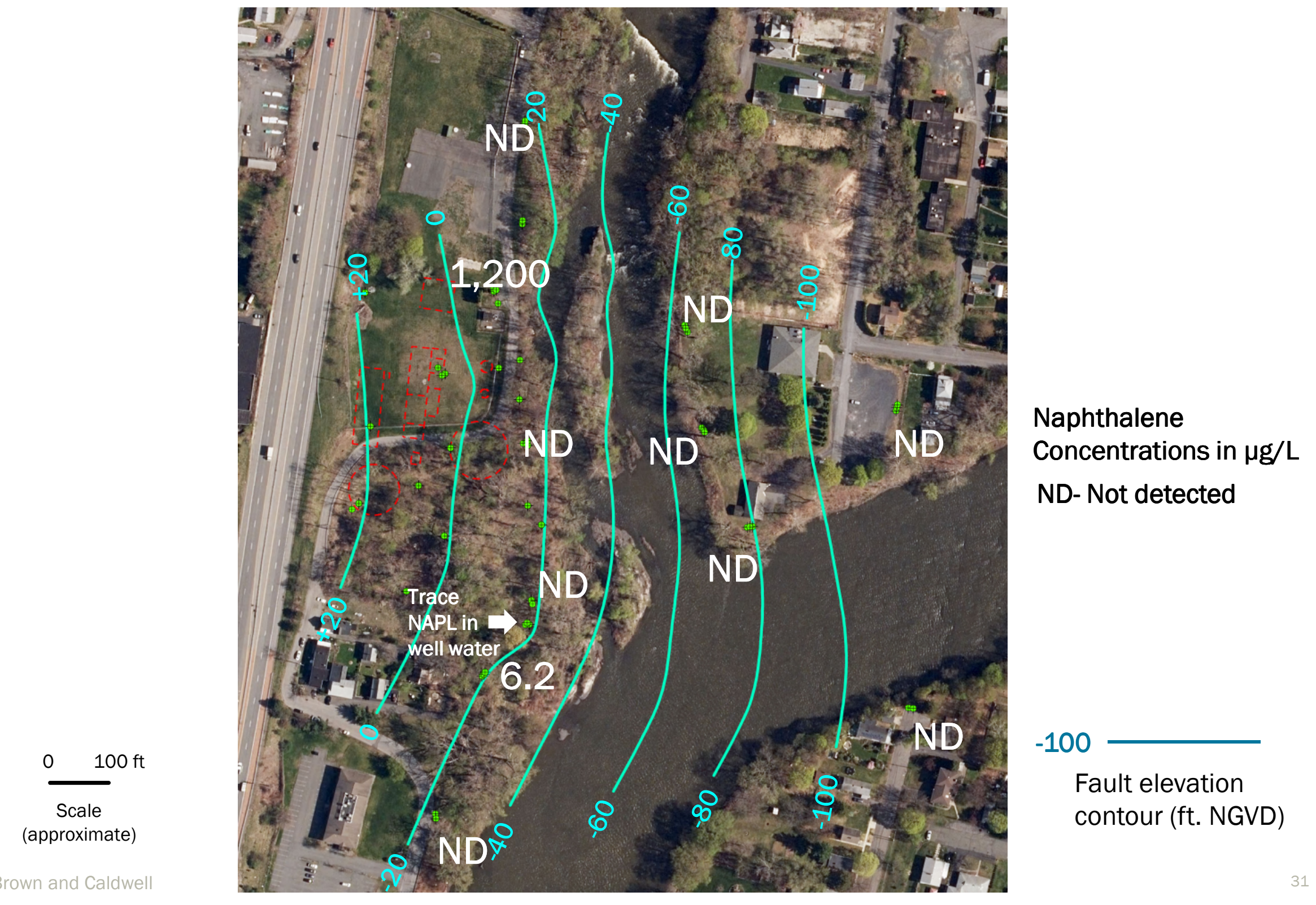




\section{Naphthalene in Groundwater in Fault}

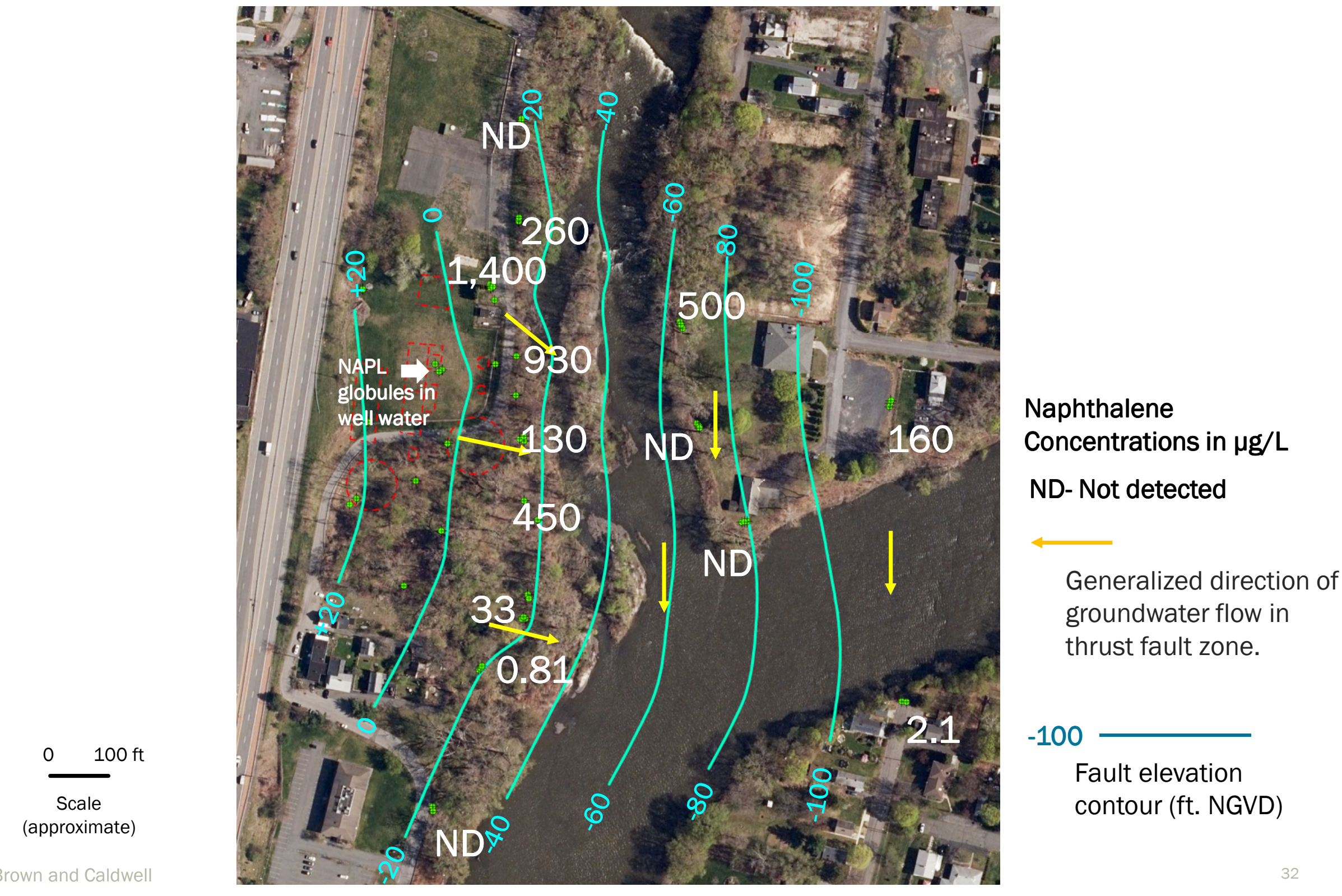




\section{Summary: \\ Extent of Impacts in Bedrock Groundwater}

- East of the Site, potential DNAPL and high dissolved-phase constituent concentrations are at depth within east-dipping thrust fault zone.

- No detections of MGP-related constituents in groundwater above the thrust fault east of site.

- Dissolved-phase constituent concentrations decrease within thrust fault zone downgradient of the potentially DNAPL impacted areas.

- Bedrock groundwater eventually discharges to the river.

- Biased-high mass flux evaluation indicates no impact to surface water in river. Surface water sampling supports this conclusion. 


\section{Conclusions}

- Identified a shallowly eastward-dipping, continuous fracture zone that serves as a water-bearing zone in bedrock.

- The geometry of this zone is similar to low-angle thrust faults identified elsewhere in the Cohoes Mélange.

- The thrust fault zone is the primary control on lateral groundwater flow and dissolved-phase constituent migration from the site in rock, and also influences DNAPL (tar) distribution.

- Other water-bearing fractures were identified above \& below that are as not as continuous. These are typically, to varying degrees, hydraulically connected to the more continuous thrust fault-related zone.

- Beneath the site, the thrust fault approaches/intersects the top of bedrock surface, facilitating entry of site constituents into this zone. 


\section{References}

- Hayman, N.W. and Kidd, W.S.F, 2002. The Champlain Thrust System in the Whitehall-Shoreham area: influence of pre- and post-thrust normal faults on the present thrust geometry and lithofacies distribution. Field trip A7, pages 7-1 to 7-24 in McLelland, J.M., and Karabinos, P. (eds), Guidebook for Field Trips in New York and Vermont. New England Intercollegiate Geological Conference $94^{\text {th }}$ Annual Meeting, and New York State Geological Association $74^{\text {th }}$ Annual Meeting, Lake George, NY, September $27^{\text {th }}-29^{\text {th }}, 2002$.

- Kidd, W.S.F. Plesch, A., and Vollmer, F.W., 1995. Field Trip A4: October 14th. Lithofacies of the Taconic Flysch, Mélange, \& Allochthon in the New York Capital District. Field Trip Guidebook for the 67th Annual Meeting of the New York State Geological Association, edited by; John I. Garver and Jacqueline Smith.

- Lim, C., Kidd, W.S.F., and Howe, S.S., 2005. Late Shortening and Extensional Structures and Veins in Western Margin of the Paconic Orogen (New York and Vermont). Journal of Geology, v. 113, p. 419438.

- Rogers, W.B., Isachsen, Y.W, Mock, T.D. and Nyahay, RE., 1990. New York State Geologic Highway Map. New York State Museum Educational Leaflet 33. 


\section{Questions?}

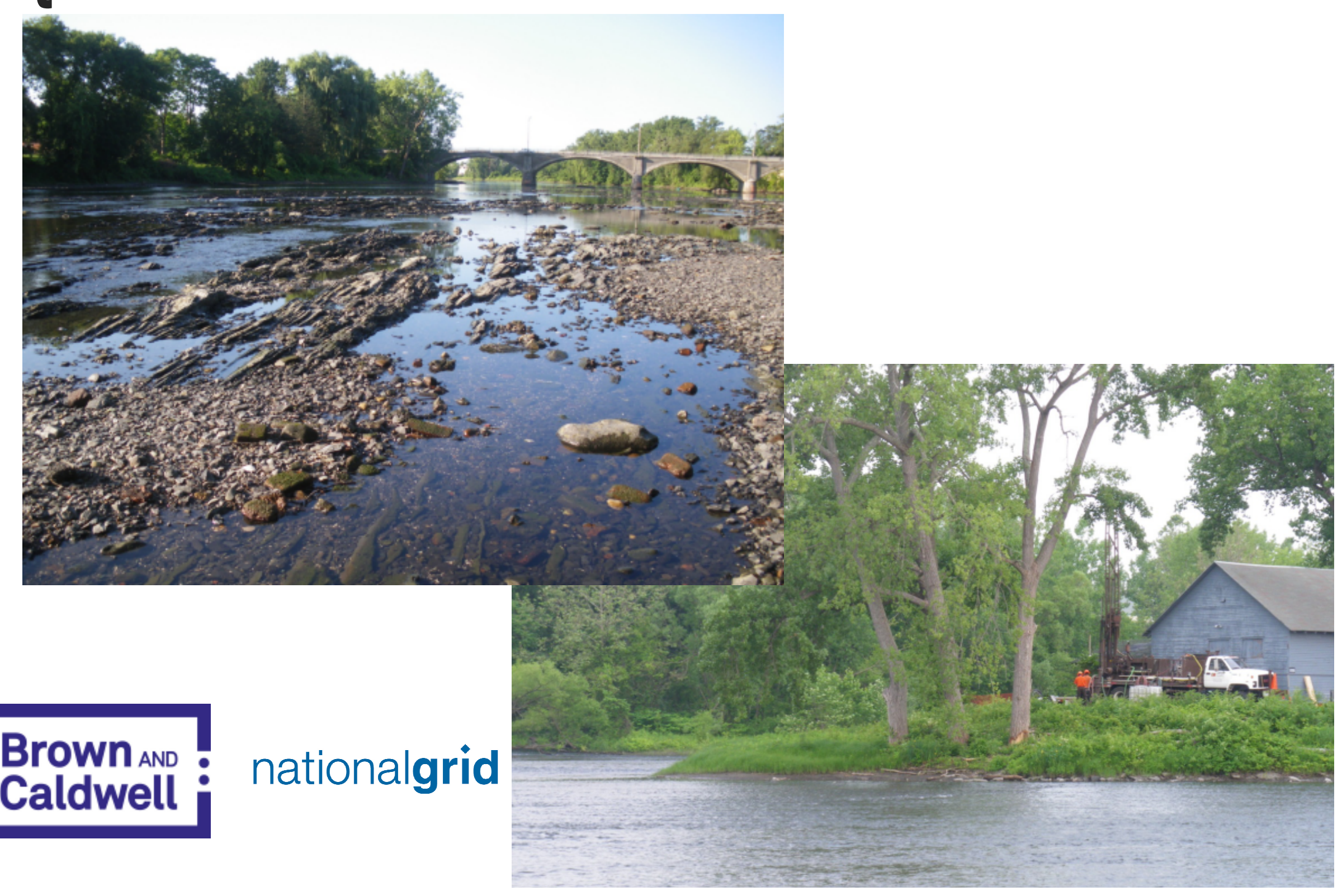

